\title{
GCU
}

Glasgow Caledonian

University

University for the Common Good

\section{Uncovering hidden geographies and socio-economic influences on fuel poverty using household fuel spend data: a meso-scale study in Scotland}

Mould, Ronald; Baker, Keith J.

Published in:

Indoor and Built Environment

DOI:

10.1177/1420326X17707326

Publication date:

2017

Document Version

Author accepted manuscript

Link to publication in ResearchOnline

Citation for published version (Harvard):

Mould, R \& Baker, KJ 2017, 'Uncovering hidden geographies and socio-economic influences on fuel poverty using household fuel spend data: a meso-scale study in Scotland', Indoor and Built Environment, vol. 26, no. 7, pp. 914-936. https://doi.org/10.1177/1420326X17707326

\section{General rights}

Copyright and moral rights for the publications made accessible in the public portal are retained by the authors and/or other copyright owners and it is a condition of accessing publications that users recognise and abide by the legal requirements associated with these rights.

Take down policy

If you believe that this document breaches copyright please view our takedown policy at https://edshare.gcu.ac.uk/id/eprint/5179 for details of how to contact us. 


\section{Uncovering hidden geographies and socio-economic influences on fuel poverty using household fuel spend data: A meso- scale study in Scotland}

Ronald Mould ${ }^{1,2}$, Keith J. Baker ${ }^{1,3}$

${ }^{1}$ School of Engineering and the Built Environment, Glasgow Caledonian University, Cowcaddens Road, Glasgow, G4 0BA, UK

2 Energy Officer (Communities), Property Services, Finance and Resources, Renfrewshire Council, Renfrewshire House, Cotton Street, Paisley, PA1 1JD, UK

${ }^{3}$ Corresponding author: keith.baker@gcu.ac.uk 


\begin{abstract}
Internationally, previous studies have investigated the impact of socio-economic and physical dwelling factors on household electricity consumption however, to date, few such studies have been conducted in the UK. A previous paper identified six studies that have accessed actual (as opposed to modelled) energy consumption or expenditure data and analysed these against sets of technical and socio-economic factors. This paper presents the results of a seventh UK study, representing the first in Scotland, the first to span urban and rural households, and the first to concentrate on households in the lower income deciles. The dataset, which includes records of household expenditure on gas used for space and water heating matched with records of dwelling and household information, is drawn from sources accessed through Renfrewshire Council and analysed using a range of standard statistical techniques. The results uncover evidence for previously unreported geographies of fuel poverty, and in so doing challenges commonly used assumptions, metrics, and approaches to policy making. Key findings include figures showing low income rural households in Scotland are spending significantly more on energy than their urban equivalents, and evidence showing that rural households on lower incomes may be spending more on heating than those on higher incomes.
\end{abstract}

Keywords

Fuel poverty, energy expenditure, income, rurality, hidden geographies 


\section{Introduction}

Internationally, many previous studies have investigated the impact of socio-economic and physical dwelling factors on household electricity consumption ${ }^{1,2}$ and the list becomes even longer when those considering other energy uses (e.g. for transport) are included. Although still relatively rare in the UK, the approach was pioneered in Australia $^{3}$ which, along with New Zealand, is relatively unique in that it both conducts extensive assessments of its building stock and also recognises the condition of fuel poverty. These studies have typically been conducted at the scale of several hundred to several thousand households, although some have been able to draw on much larger datasets. Their key strength is that they use real data on household energy consumption, as opposed to modelled or estimated data, which is obtained variously from central and local government, energy suppliers, housing associations, or other data managers. This is matched with data on the dwellings and households held by those organisations, and may be further verified through cross-checking with other sources and / or surveying. The resulting datasets are empirically robust and are able to produce statistically significant evidence on energy consumption within and between sample populations. As such they represent a useful balance between using abstracted or modelled data across large populations and the costs of studies based on intensive monitoring. Jones et al (2015) ${ }^{1}$ identify six such studies conducted in the UK to date $e^{2,4,5,6,7,8}$. All have been limited in the range of factors they have been able to examine, but typically include the number and type of occupants; age, economic status and education of the household reference person; floors and floor area; space and water heating; proportion of low energy lighting (see Table 1). These factors are commonly accepted as 'known' influences on household energy consumption in the UK and are used variously in modelling and policy making however, as the results of these studies show, the strength of evidence for the validity of these factors varies, and is sometimes contradictory.

This paper presents the results of a seventh such study conducted in Renfrewshire, Scotland, which is, as far as the authors are aware, the first such UK study to be conducted in Scotland, the first to span urban and rural households, and the first to focus on the 'hard to reach' populations in the lowest income deciles. The energy data collected was for expenditure on gas for a population of households using gas for their central and hot water heating systems. This means that although the figures cannot be compared to the regional figures for fuel poverty (as this is defined by total energy consumption), they usefully limit the analyses to energy used for heating, as per the Scottish definition of fuel poverty. See the section 'Defining fuel poverty' for a full description of the Scottish definition and how it relates to those used in the UK and internationally.

The use of Renfrewshire as a study area exploited an opportunity to gather data from council-owned housing stock from one of the few Scottish local authorities whose boundaries include substantial urban and rural areas (Scotland has a strong urban-rural divide and local authority boundaries commonly follow these delineations). Furthermore, whilst biased towards households on lower incomes, the population does include small numbers of higher earners who have retained their tenancies in council housing, which reflects the wider demographics of council tenants in Scotland ${ }^{9}$. 
Based on the findings from the analyses, we argue that whereas energy consumption amongst more affluent households can largely be explained by dwelling conditions and household demographics (meaning policies to improve household energy efficiency can reasonably focus on delivering technical improvements and household behaviour change), fuel poverty is an inherently more complex condition. This is due to it being both an outcome of, and an influence on, a much wider and more complex range of other influences, including household expenditure and occupant health ${ }^{10}$.

Yet, and partly due to a simple lack of evidence, policies to address fuel poverty remain rooted in the use of the simpler and more conventional mechanisms and assumptions used for driving energy efficiency, which we argue are insufficiently sensitive to the needs of individual householders and the 'hidden geographies' of the distributions of the fuel poor. The results presented here provide evidence to question the fitness-for-purpose of two mechanisms commonly used as part of identifying fuel poor households, and some evidence for questioning the assumption that rural households necessarily spend more on heating as their income increases.

This research has been enabled by a series of incremental changes to government policies relating to how household data can be used and shared within the public sector, particularly the extended data sharing powers provided by the 2012 revision of the UK's Welfare Reform Act ${ }^{11}$. These revisions increasingly allow for public bodies to share and analyse personal data (as defined by the Act) for the purposes of improving the levels of support available to them - in this case to develop recommendations for how fuel poor households can be better identified and targeted. These changes, along with a studentship / secondment arrangement between Glasgow Caledonian University and Renfrewshire Council, allowed the authors to access energy bills and other data on a sample of households in Renfrewshire without requiring householder consent, providing that raw data was not transferred away from the council's data management systems, and that all data was treated in strict accordance with the UK's Data Protection Act (1998) ${ }^{12}$.

In terms of how this and the other studies are able to address influences on fuel poverty, it should be noted that the current Scottish definition covers all fuel consumption (including electricity), even though the problem is essentially driven by heating energy consumption. This naturally has implications for how the findings of each study may be interpreted and applied (or not) to the Scottish context, according to the type(s) of energy data collected and the heating systems in use, making direct comparisons difficult. However, at this level of analysis it is the evidence they present for the strengths, or otherwise, of 'known' influences on fuel poverty (e.g. income), and how measures of those influences are incorporated into policies and programmes, that is pertinent to this study and the new research that builds on it. As such, this study sets out the empirical foundations for further questioning the validity of some those 'known' influences as metrics or proxies for measuring fuel poverty and / or for identifying fuel poor households. 
Table 1. Socio-economic studies of household energy consumption or fuel spend in the UK

\begin{tabular}{|c|c|c|c|c|c|c|c|}
\hline Author(s) & $\begin{array}{l}\text { Area / } \\
\text { region }\end{array}$ & No. Households & Dwelling Types & $\begin{array}{l}\text { Energy } \\
\text { consumption / spend } \\
\text { data sources }\end{array}$ & Other data sources & $\begin{array}{l}\text { Fuel types and } \\
\text { heating systems }\end{array}$ & Main factors studied \\
\hline $\begin{array}{l}\text { Baker \& } \\
\text { Rylatt, } 2008^{4}\end{array}$ & $\begin{array}{l}\text { Leicester } \\
\text { and } \\
\text { Sheffield } \\
\text {, England }\end{array}$ & $\begin{array}{l}148 \text { matched with } \\
\text { electricity and gas } \\
\text { consumption data }\end{array}$ & $\begin{array}{l}\text { Terraces } \\
\text { (Leicester), and } \\
\text { detached and semi- } \\
\text { detached (Sheffield) }\end{array}$ & $\begin{array}{l}\text { Mandate forms used } \\
\text { to release } \\
\text { consumption data } \\
\text { from suppliers, } \\
\text { collected by the } \\
\text { Department of Trade } \\
\text { and Industry }\end{array}$ & $\begin{array}{l}\text { Household surveys } \\
\text { Ordinance Survey }\end{array}$ & $\begin{array}{l}\text { Gas central } \\
\text { heating and } \\
\text { secondary gas / } \\
\text { electric heating }\end{array}$ & $\begin{array}{l}\text { Dwelling type, Tenure, } \\
\text { Dwelling age, Floor area } \\
\text { Dwelling characteristics*, } \\
\text { Occupancy, Employment, } \\
\text { Education, Appliances }\end{array}$ \\
\hline $\begin{array}{l}\text { Druckman \& } \\
\text { Jackson, } \\
2007^{5}\end{array}$ & $\begin{array}{l}\text { England } \\
\text { - case } \\
\text { study } \\
\text { areas in } \\
\text { the North } \\
\text { West and } \\
\text { South } \\
\text { East } \\
\end{array}$ & $\begin{array}{l}\text { Approx. } 7,000 \\
\text { matched with energy } \\
\text { expenditure data }\end{array}$ & $\begin{array}{l}\text { Detached, semi- } \\
\text { detached, terraces, } \\
\text { bungalows, flats }\end{array}$ & $\begin{array}{l}\text { Energy spend from } \\
\text { UK Expenditure on } \\
\text { Fuel and Food } \\
\text { Survey (Office of } \\
\text { National Statistics) } \\
\\
\text { Modelled energy } \\
\text { consumption }\end{array}$ & $\begin{array}{l}\text { Census } 2001 \\
\text { Electoral Roll } \\
\text { Local Area } \\
\text { Characteristics } \\
\text { Database }\end{array}$ & $\begin{array}{l}\text { Mixed - gas, } \\
\text { electric, and solid } \\
\text { / liquid fuels }\end{array}$ & $\begin{array}{l}\text { Dwelling type, Income, } \\
\text { and disposal income, } \\
\text { Employment } \\
\text { Tenure, Indices of } \\
\text { Multiple Deprivation }\end{array}$ \\
\hline $\begin{array}{l}\text { Hamilton et } \\
\text { al., } 2013^{6}\end{array}$ & England & $\begin{array}{l}11,685,235 \\
\text { household records } \\
\text { matched with } \\
\text { electricity data } \\
9,785,503 \text { household } \\
\text { records matched with } \\
\text { gas data. However, } \\
\text { sample sizes reduce } \\
\text { significantly due to } \\
\text { missing data } \\
\end{array}$ & $\begin{array}{l}\text { Detached, semi- } \\
\text { detached, terraces, } \\
\text { bungalows, flats / } \\
\text { maisonettes }\end{array}$ & $\begin{array}{l}\text { Meter point data } \\
\text { provided by the } \\
\text { Department for } \\
\text { Energy and Climate } \\
\text { Change }\end{array}$ & $\begin{array}{l}\text { Home Energy } \\
\text { Efficiency Database } \\
\text { (HEED) }\end{array}$ & $\begin{array}{l}\text { Electricity and } \\
\text { gas data, mixed } \\
\text { heating systems }\end{array}$ & $\begin{array}{l}\text { Dwelling type, Tenure } \\
\text { Dwelling age, Dwelling } \\
\text { characteristics*, Energy } \\
\text { ratings (SAP/NHER } \\
\text { ratings), Energy tariffs } \\
\text { (standard / 'Economy 7'), } \\
\text { Energy efficiency } \\
\text { upgrades, Renewable } \\
\text { energy technologies }\end{array}$ \\
\hline $\begin{array}{l}\text { Jones \& } \\
\text { Lomas, } 2015^{2}\end{array}$ & $\begin{array}{l}\text { Leicester } \\
\text {, England }\end{array}$ & $\begin{array}{l}315 \text { matched with } \\
\text { energy data, } 575 \text { total }\end{array}$ & $\begin{array}{l}\text { Detached, semi- } \\
\text { detached, terraces, } \\
\text { flats }\end{array}$ & $\begin{array}{l}256 \text { from meter } \\
\text { readings, } 59 \text { released } \\
\text { by energy suppliers } \\
\text { using a mandate form }\end{array}$ & Household surveys & Electricity only & $\begin{array}{l}\text { Dwelling type, Tenure, } \\
\text { Dwelling age, Floor area } \\
\text { Dwelling characteristics*, } \\
\text { Occupancy, Employment, } \\
\text { Education, Appliances }\end{array}$ \\
\hline
\end{tabular}




\begin{tabular}{|c|c|c|c|c|c|c|c|}
\hline $\begin{array}{l}\text { Summerfield } \\
\text { et al., } 2007^{7}\end{array}$ & $\begin{array}{l}\text { Milton } \\
\text { Keynes, } \\
\text { England }\end{array}$ & $\begin{array}{l}\text { Original sample of } \\
160,29 \text { monitored for } \\
\text { temperatures, } 13 \text { of } \\
\text { these used for the } \\
\text { latest study }\end{array}$ & $\begin{array}{l}35 \text { different designs } \\
\text { of low energy } \\
\text { homes }\end{array}$ & $\begin{array}{l}\text { Original study used } \\
\text { hourly energy } \\
\text { monitoring }\end{array}$ & $\begin{array}{l}\text { On-site surveys, } \\
\text { original technical } \\
\text { data }\end{array}$ & $\begin{array}{l}\text { Mixed types } \\
\text { including some } \\
\text { novel low energy } \\
\text { systems }\end{array}$ & $\begin{array}{l}\text { Dwelling type, } \\
\text { Temperature, Floor area, } \\
\text { Dwelling characteristics*, } \\
\text { Energy efficiency and } \\
\text { renewable energy } \\
\text { technologies, Occupancy, } \\
\text { Employment }\end{array}$ \\
\hline Wyatt, $2013^{8}$ & $\begin{array}{l}\text { England } \\
\text { and } \\
\text { Wales }\end{array}$ & $\begin{array}{l}3,528,100 \text { matched } \\
\text { with electricity } \\
\text { consumption data } \\
2,494,300 \text { matched } \\
\text { with gas consumption } \\
\text { data }\end{array}$ & $\begin{array}{l}\text { Detached, semi- } \\
\text { detached, terraces, } \\
\text { bungalows, } \\
\text { converted flats, } \\
\text { purpose-built flats }\end{array}$ & $\begin{array}{l}\text { National Energy } \\
\text { Efficiency Database } \\
\text { (NEED) }\end{array}$ & $\begin{array}{l}\text { Valuation Office } \\
\text { Agency Property } \\
\text { Database }\end{array}$ & $\begin{array}{l}\text { Gas and electric } \\
\text { systems }\end{array}$ & $\begin{array}{l}\text { Dwelling type, Dwelling } \\
\text { age, Floor area, Tenure, } \\
\text { Occupancy, Income, } \\
\text { Dwelling characteristics*, } \\
\text { Energy efficiency } \\
\text { measures }\end{array}$ \\
\hline $\begin{array}{l}\text { The } \\
\text { Renfrewshire } \\
\text { study }\end{array}$ & $\begin{array}{l}\text { Renfrews } \\
\text { hire, } \\
\text { Scotland }\end{array}$ & $\begin{array}{l}513 \text { matched with gas } \\
\text { data }\end{array}$ & $\begin{array}{l}\text { 1,346 domestic gas } \\
\text { bills, reduced to } \\
513 \text { by excluding } \\
\text { estimated readings }\end{array}$ & $\begin{array}{l}\text { Energy spend data } \\
\text { from fuel bills held } \\
\text { by Renfrewshire } \\
\text { Council }\end{array}$ & $\begin{array}{l}\text { Household surveys } \\
\text { Home Energy } \\
\text { Efficiency Database } \\
\text { (HEED) } \\
\text { Scottish Indices of } \\
\text { Multiple } \\
\text { Deprivation } \\
\text { (SIMDs) } \\
\text { Other data held by } \\
\text { the council's support } \\
\text { services }\end{array}$ & $\begin{array}{l}\text { Gas-fuelled main } \\
\text { and secondary } \\
\text { heating systems }\end{array}$ & $\begin{array}{l}\text { Dwelling type, Occupancy, } \\
\text { Income deciles from } \\
\text { Scottish } \\
\text { Indices of Multiple } \\
\text { Deprivation, Rurality }\end{array}$ \\
\hline
\end{tabular}

*Typically includes numbers of floors, rooms, bedrooms, wall type, roof type, window type, insulation, heating systems, etc. 


\section{Background}

\section{Defining Fuel Poverty}

The European Union, along with a growing number of other nations, recognises the broad condition of 'energy poverty' ${ }^{13}$, but no universal definition exists ${ }^{14}$ and the EU is not currently proposing to adopt one ${ }^{15}$. Within the EU there are difficulties in integrating definitions of energy poverty into national frameworks, at least in part due to the diversity of actual energy use characteristics ${ }^{16,17}$, and the variability in the resolution and nature of relevant data collected by individual states makes it highly problematic to agree and implement any universal definition ${ }^{18,19,20}$. As such, the current EU definitions, where they exist, vary widely ${ }^{21}$; whilst some member states are unwilling to admit that the problem exists $^{22}$. Currently under one third of EU Member States recognise the condition of energy poverty which is generally defined more broadly as households not being able to meet all their required energy needs (e.g. for cooking, as well as heating) at an affordable $\operatorname{cost}^{23}$.

However, within the UK, and also Ireland, Australia and New Zealand ${ }^{24}$, the condition of fuel poverty has been recognised by government for well over a decade, and in Scotland it has long been acknowledged as a serious problem. In 2001 the Scottish Executive (now the Scottish Government) pledged to eliminate the problem as far as practicable by November $2016^{25,26}$ however, since then the figure has risen significantly, and the Scottish Government currently estimates $34.9 \%$ of households are living in fuel poverty, with $9.5 \%$ classified as living in extreme fuel poverty, and figures for elderly households living in island areas can be in excess of $70 \%{ }^{9}$.

At present, the Scottish Government's powers to tackle fuel poverty are semi-devolved from those of the UK Government at Westminster. Energy policy is retained by Westminster and exercised principally through the Electricity Act (last amended 1989) ${ }^{27}$, whilst revenue from UK-wide energy efficiency schemes such as the current Energy Company Obligation (ECO) ${ }^{28}$ is administered centrally by the UK Treasury, with Scotland receiving a share of those revenues and some control over how those funds are used. (Note that until mid-2015 this had been the responsibility of the Department for Energy and Climate Change (DECC)).

However, the Scottish Government has control over planning, principally through the National Planning Framework for Scotland (NPF) ${ }^{29}$ which it can, and does, use to influence energy policy, for example by blocking new nuclear power plants. The Scottish Government also has variously devolved responsibilities for health and welfare, including the power to raise additional funding and deliver measures through developing its own national schemes, such as the Home Energy Efficiency Programmes ${ }^{30}$ and the forthcoming Scottish Energy Efficiency Programme (SEEP) ${ }^{31}$. Finally, the Scottish Government has further devolved some powers to design and deliver schemes to Local Authorities. Understandably, and even to those familiar with the legislatures, it is a sometimes confusing and frequently changing system. 
As regards the definition itself, until 2013 the UK as a whole shared a common definition of fuel poverty as a household needing to spend more than $10 \%$ of household income to maintain a standard thermal regime, and extreme fuel poverty as needing to spend more than $20 \%$ to do so. This core definition, which is also used in Ireland, Australia and New Zealand, was first fully articulated by Brenda Boardman of Oxford University ${ }^{32,33,34}$, and has since been expanded on and diversified ${ }^{35,36}$. However, in 2013 an alternative 'low income, high costs' definition, known as the 'Hills Definition' ${ }^{37}$, was adopted for England (only) by the Westminster Government. Figure 1 shows the number of households in England classified as being fuel poor under the conventional $10 \%$ of income and Hills definitions.

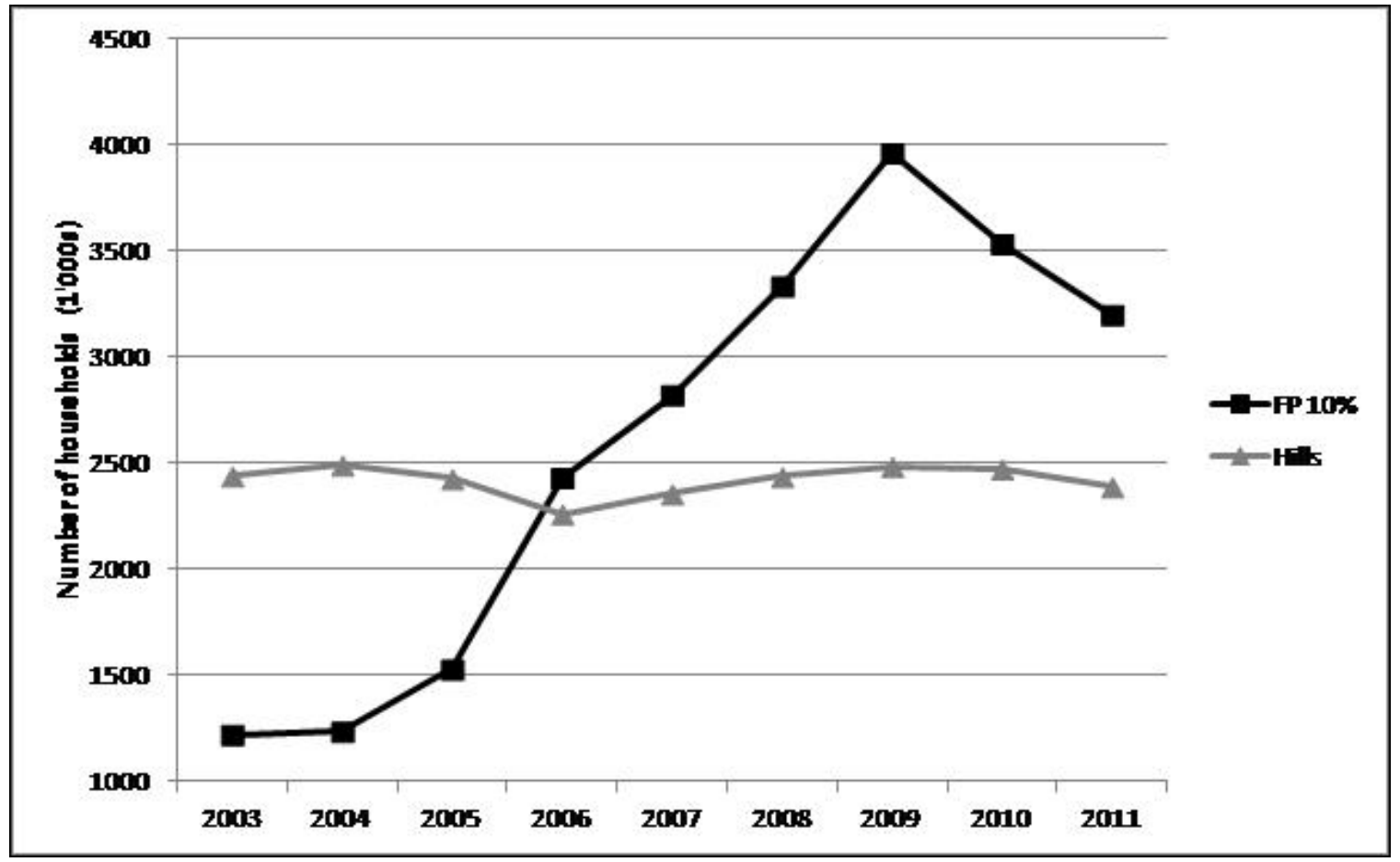

Figure 1. Numbers of households in England classified as being fuel poor under the low income - high costs (Hills) definition and the $10 \%$ of income definition Source: DECC, $2013^{38}$

In line with the World Health Organisation's definition of a 'satisfactory heating regime ${ }^{39}$, the Scottish Government's definition classifies a household as being fuel poor if more than $10 \%$ of income (including any social welfare payments) is needed to maintain a heating regime of $21^{\circ} \mathrm{C}$ in the living room and $18^{\circ} \mathrm{C}$ in other rooms for a period of 9 hours in every 24 (or 16 in 24 over the weekend); with two hours being in the morning and seven hours in the evening. For elderly and infirm households, this is increased to $23^{\circ} \mathrm{C}$ in the living room and $18^{\circ} \mathrm{C}$ in other rooms, to be achieved for 16 hours in every $24^{26}$. Providing a full summary of the current legislative environment for fuel poverty in Scotland is beyond the scope of this paper, but a current and exhaustive summary can be found in a review conducted for Citizens Advice Scotland ${ }^{10}$. 


\section{Understanding Fuel Poverty in Scotland and the UK}

Fuel poverty is a highly complex and multidisciplinary policy problem. Whereas making standard energy efficiency improvements to an average home should lead to relatively predictable energy and emissions savings, bringing a fuel poor home up to modern standards ${ }^{*}$ requires a much more complex set of interventions, and behavioural changes, that add significant uncertainty when modelling the likely costs and savings ${ }^{40}$. Household energy consumption, even within the archetypes commonly used for supporting policy making, is also highly variable and may not be normally distributed, as shown by a study conducted for the UK's Office of Gas and Electricity Markets (Ofgem) ${ }^{41}$. This study used energy consumption data for twelve consumer archetypes, and is useful for demonstrating that policies for improving energy efficiency, which like those for fuel poverty tend to focus on delivering reductions in heating demand, have had a an impact on reducing household gas bills. However, the study does not attempt to account for the influence of poorer householders self-limiting their energy use, and by not addressing this and other non-standard household behaviours and circumstances it also demonstrates the limitations of policy approaches which attempt to group populations into small numbers of archetypes, for whom equally limited 'solutions' are then defined.

Furthermore, the use of the UK's Standard Assessment Procedure (SAP) and reduced dataset SAP (rdSAP) assessments, which are the standard models for reporting energy demand and greenhouse gas emissions under the EU's Energy Performance of Buildings Directive (EPBD; European Union, 2010) ${ }^{42}$ is far from ideal for supporting policy making in Scotland. Both SAP and its non-domestic equivalent, the Simplified Building Energy Model (SBEM), have been subject to some criticism for under-estimating demand and for being insufficiently sensitive to Scottish geographies and climates, and the nature of the Scottish building stock ${ }^{43,44,45,46,47,48,49,50}$. At an aggregate level the Scottish Government also uses its Domestic Energy Model for Scotland (DEMScot2) to model carbon emissions from energy efficiency interventions to housing, but this may also under-predict energy demand ${ }^{51}$. It should also be noted that another weakness and source of uncertainty in official statistics is that those for the impacts of 'behavioural changes' commonly conflate one-off behaviours such as installing insulation with repeated behaviours and lifestyle changes (e.g. switching off unused lights and using appliances more efficiently).

There is also the problem of how, and how strongly, the rebound and prebound effects manifest themselves amongst fuel poor households compared to other socio-economic groups. The 'rebound effect', also known as Jevons' Paradox, refers to the phenomenon that actual energy savings are often lower than models predict because households tend to take some of the energy efficiency gains in the form of increased thermal comfort rather than reduced energy use. Furthermore, the effect is not simply limited to heating and may include wider behaviour changes, for example to transport behaviours, which result in increased household energy consumption ${ }^{51,52,53,54}$. To date there is relatively little evidence of the variation of the rebound effect across different socio-economic groups

\footnotetext{
* In Scotland the current standards for regulating retrofit are the Scottish Housing Quality Standard (SHQS) and the Energy Efficiency Standard for Social Housing (EESH), and the Building Standards for new build.
} 
however, one German study on domestic heating measures found it to be higher for households and office workers in lower socio-economic groups ${ }^{55}$. These results are consistent with a more recent study into transport behaviour in Germany, which found that that the effect was higher (up to $49 \%$ ) for commuters from more disadvantaged groups $^{56}$.

The prebound effect arises from households under-consuming energy, for example by choosing or adapting to lower internal temperatures, as well as other behaviours to deliberately limit energy consumption. This effect may result from householders choosing or adapting to lower internal temperatures, but it also results from behaviours to limit energy use, and so is a strong indicator of fuel poverty. Galvin \& Sunikka-Blank $(2016)^{57}$ show why it cannot be assumed that households with a high prebound effect will have a lower rebound effect after an energy efficiency retrofit, as cultural and social influences affect desire and willingness to pay for higher levels of heating and other forms of take back behaviours.

In addition, as noted in the Introduction, fuel poverty is both an outcome of and an influence on other household conditions, including expenditure and health. The relationships between fuel poverty and health, alone, are highly complex however, there is a broad and substantial evidence base from which to conclude that a causal relationship exists between housing quality and householders experiencing respiratory illness, mediated by dampness, mould and indoor air quality $^{58,59,60,61,62,63,64,65,66,67,68,69,70,71,72,73,74,75,76,77,78,79}$. Furthermore, these have been found to be dose-response relationships (i.e. occupants experience greater severity of illness, and for longer, in relation to exposure to poor housing conditions ${ }^{75}$, and significant regardless of socio-economic group ${ }^{72}$.

Finally, the ability and capacity of householders to manage their energy consumption and expenditure, and their resilience to prices rises, is both an influence on and an outcome of their vulnerability. Energy and food have been found to be the two main expenses that low income households ration in response to financial stress ${ }^{10,80,81}$, and further research is needed to better understand these relationships and build capacity and resilience amongst vulnerable fuel poor households ${ }^{10,14,82}$. This relates back to the problem of the greater uncertainties in understanding and modelling the energy consumption and expenditure of these households, as they are more likely to engage in non-standard energy behaviours, and also emphasises the need for policies designed to target them to provide more individualized support that goes beyond the installation of technical measures and education and awareness raising about behavioural changes. Such research could also therefore be useful in developing a more internationalised understanding as it is possible to find examples of energy poverty related to social exclusion caused by poor physical and mental health and wellbeing ${ }^{83}$.

In light of this and other evidence it is natural to ask why fuel poverty levels have risen to the point that one in three Scottish households cannot afford to maintain a reasonable level of warmth ${ }^{84}$, and why the problem is now endemic amongst the poorest and most 
vulnerable socio-economic groups. The root of the problem may lie in the failure of the conventional quantitative social science methods used to address highly complex policy problems ${ }^{85}$. Here again, the Ofgem study ${ }^{41}$ is an excellent example of the validity of this important criticism, as it defines a limited range of household archetypes and, unsurprisingly, finds a wide variation in consumption within them.

In contrast, the socio-economic studies show, to a greater or lesser extent, that statistically significant relationships exist between some factors (for example the total number of individuals in a household, household income, etc) and the likelihood of being a higher and / or lower energy consumer. However, perhaps more importantly, they demonstrate the wide variance in energy consumption even when controlling for 'known' factors, and by doing so question the validity of the conventional archetype-driven approaches commonly used to inform policy making. An alternative is a risk-based approach to targeting engagement and support at those most likely to be in need by prioritising the use of the most robust data available to policy makers through local government and public services, and this study provides further evidence on how such an approach could be developed using data that is already being collected but not sufficiently utilised.

The value of using this data, which is already available to government bodies but subject to various restrictions and not normally accessible to researchers, is demonstrated by the key findings of this study, which uses this data challenge conventional thinking on a number of assumptions that commonly underlie policymaking for addressing fuel poverty across the urban-rural divide.

\section{Measuring Fuel Poverty}

At a basic level the condition of fuel poverty results from an interaction of dwelling energy efficiency, household income, and fuel prices however, these are relative and imprecise measures which are also influenced by household behaviour, and the data needed to measure them can be difficult and costly to collect ${ }^{37,78,86}$. Furthermore, more recent work has posited the value of incorporating measures of vulnerability, and in particular mental health, into the assessment, as evidence suggests these are both influences on and outcomes of fuel poverty ${ }^{10}$.

In Scotland the two metrics most commonly used for quantifying households in fuel poverty are the hybrid modelling / survey method used as part of the Scottish House Condition Survey (SHCS) ${ }^{9}$, and the income domain of the Scottish Indices of Multiple Deprivation (SIMD) ${ }^{87}$ however, neither of these are ideal.

The SHCS method, the primary mechanism for reporting fuel poverty, uses modelled dwelling energy performance (using the BREDEM 12 model, which underpins SAP assessments) to calculate the cost of maintaining the standard heating regime and the income of the highest earner in the household, collected from face to face interviews. However, no actual evidence of income is collected and, due to the small sample sizes, the results are restricted to being reported as a three-year rolling average. Table 2 shows 
the Scottish local authorities ranked by the percentage of households in fuel poverty according to this metric.

The SIMD is the Scottish Government's official tool for identifying areas of deprivation, using seven domains that are scored over seven different domains (income, access, education, housing, crime, employment, and health) which are summed to give an overall score of multiple deprivation as a single index. SIMD are reported as data zones which contain, on average, around 350 households (around 800 people), and correspond to administrative and political boundaries. The datazones are similar to the super output areas used in England, meaning the results of analyses using them are broadly comparable with English studies (such as Morris et al., 2016) ${ }^{88}$. However, as they are population-based, the datazones vary significantly in size, meaning that low density rural data zones covering multiple small population centres would be expected to be less homogenous than the small datazones in dense urban areas - a problem which is more significant in Scotland due to its more distinct urban-rural divide and the nature and distributions of rural and island populations. 
Table 2. Scottish Local Authorities ranked by \% population in fuel poverty

\begin{tabular}{|c|c|c|c|c|c|c|}
\hline & \multicolumn{6}{|c|}{$\begin{array}{l}\text { Fuel poverty ranking. } \\
\text { Ranked by percent of LA population in fuel poverty }\end{array}$} \\
\hline & $\begin{array}{l}2003- \\
06\end{array}$ & $\begin{array}{l}2004- \\
07\end{array}$ & $\begin{array}{l}2005- \\
08\end{array}$ & $\begin{array}{l}2007- \\
09\end{array}$ & $\begin{array}{l}2008- \\
10 \\
\end{array}$ & $\begin{array}{l}2009- \\
11 \\
\end{array}$ \\
\hline Aberdeen City & 23 & 26 & 22 & 30 & 29 & 23 \\
\hline Aberdeenshire & 9 & 6 & 4 & 11 & 12 & 9 \\
\hline Angus & 19 & 10 & 10 & 9 & 12 & 19 \\
\hline Argyll and Bute & 3 & 2 & 7 & 9 & 4 & 3 \\
\hline Clackmannanshire & 29 & 30 & 32 & 30 & 32 & 29 \\
\hline Dumfries and Galloway & 8 & 4 & 3 & 3 & 3 & 8 \\
\hline Dundee City & 29 & 29 & 29 & 25 & 19 & 29 \\
\hline East Ayrshire & 14 & 17 & 22 & 17 & 12 & 14 \\
\hline East Dunbartonshire & 24 & 21 & 22 & 17 & 22 & 24 \\
\hline East Lothian & 19 & 19 & 22 & 20 & 22 & 19 \\
\hline East Renfrewshire & 18 & 14 & 14 & 17 & 19 & 18 \\
\hline City of Edinburgh & 24 & 21 & 27 & 25 & 26 & 24 \\
\hline Eilean Siar & 1 & 1 & 1 & 1 & 1 & 1 \\
\hline Falkirk & 28 & 21 & 17 & 28 & 27 & 28 \\
\hline Fife & 14 & 13 & 13 & 11 & 11 & 14 \\
\hline Glasgow City & 19 & 19 & 17 & 20 & 22 & 19 \\
\hline Highland & 5 & 4 & 6 & 5 & 4 & 5 \\
\hline Inverclyde & 12 & 14 & 15 & 25 & 19 & 12 \\
\hline Midlothian & 14 & 17 & 17 & 14 & 17 & 14 \\
\hline Moray & 6 & 8 & 10 & 11 & 10 & 6 \\
\hline North Ayrshire & 12 & 12 & 15 & 20 & 12 & 12 \\
\hline North Lanarkshire & 29 & 26 & 17 & 14 & 22 & 29 \\
\hline Orkney Islands & 2 & 3 & 2 & 2 & 2 & 2 \\
\hline Perth and Kinross & 6 & 4 & 7 & 5 & 9 & 6 \\
\hline Renfrewshire & 24 & 26 & 22 & 28 & 29 & 24 \\
\hline Scottish Borders & 11 & 9 & 7 & 4 & 8 & 11 \\
\hline Shetland Islands & 4 & 6 & 4 & 8 & 6 & 4 \\
\hline South Ayrshire & 9 & 11 & 11 & 14 & 12 & 9 \\
\hline South Lanarkshire & 19 & 14 & 11 & 5 & 6 & 19 \\
\hline Stirling & 14 & 21 & 17 & 24 & 17 & 14 \\
\hline West Dunbartonshire & 24 & 21 & 27 & 29 & 27 & 24 \\
\hline West Lothian & 32 & 30 & 31 & 20 & 11 & 32 \\
\hline
\end{tabular}

Source: Based on Scottish Government, $2012^{89}$. 
The income domain is based on data collected by the UK's Department of Work and Pensions (DWP), and the number of data zones that fall within the $0-15 \%$ band for the income domain of the SIMD is reported by the Scottish Government and commonly used as a proxy measure for identifying fuel poor households and targeting funding (the $0-20 \%$ and $0-25 \%$ income bands and $0-15 \%$ overall SIMD band have also been used). The justification for the use of income as a proxy measure is based on the high level correlation between household income and expenditure on gas (see Figure 2) however, as the results of this study show, this assumption is questionable at the lowest incomes levels, particularly for households in rural and deprived areas.

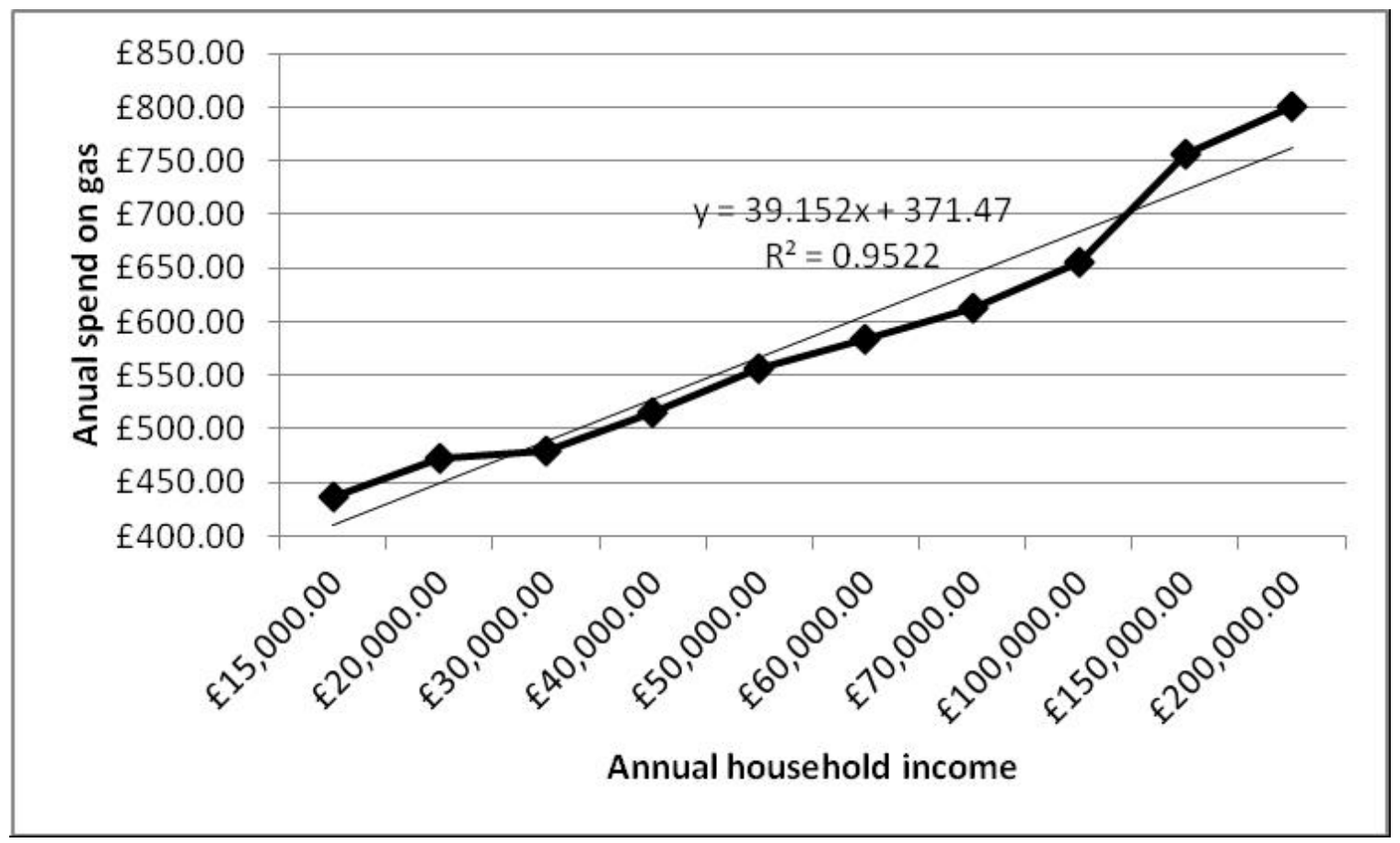

Figure 2. Annual spend on gas versus annual household income for the UK Source: DECC, $2015^{90}$

The overall SIMD score is calculated from seven weighted factors, of which income, along with employment, has the greatest weighting, as shown in Table 3. Table 4 shows the Scottish local authorities ranked by the percentage of households in fuel poverty according to this metric. However, when interpreting this data it is important to note that, although they were originally demarked to include $\sim 500$ households, due to a combination of socio-demographic changes and patterns of demolition and new build, the populations of the data zones range from several hundred to several thousand (mean average 822 , range from 0 to 10,372$)^{91}$.

This, combined with the significantly different geographic areas needed to capture similar numbers of households in a country with a very distinct urban-rural divide mean that it is easy to skew data zone-based statistics, for example, income data for (generally poorer) 
sparsely populated rural data zones can easily be skewed by the presence of small numbers of wealthy landowners.

Table 3. Weighted values for Scottish Indices of Multiple Deprivation (SIMD) domains

\begin{tabular}{ll}
\hline Income $^{1}$ & 0.28 \\
\hline Access $^{2}$ & 0.09 \\
\hline Education $^{3}$ & 0.14 \\
\hline Housing $^{4}$ & 0.02 \\
\hline Crime $^{5}$ & 0.05 \\
\hline Employment $^{6}$ & 0.28 \\
\hline Health $^{7}$ & 0.14 \\
\hline
\end{tabular}

Source: Scottish Government, $2013^{87}$.

${ }^{1}$ Income: based on DWP data

${ }^{2}$ Access: based on drive and public transport journey times to essential services.

${ }^{3}$ Education: based on the achievements of school children, number of adults with no qualifications and school absences.

${ }^{4}$ Housing: based on the number of overcrowded households and those with no $\mathrm{CH}$.

${ }^{5}$ Crime: based on reported crime rates

${ }^{6}$ Employment: based on those unemployed for 12 months or more and those in receipt of incapacity of disablement allowances.

${ }^{7}$ Health: based on the mortality ratio, hospital admittances and prescription rates for anxiety, depression or psychosis. 
Table 4. Scottish Local Authorities ranked by \% Scottish Indices of Multiple Deprivation (SIMD) in 0-15 band

\begin{tabular}{|c|c|c|c|c|}
\hline & \multicolumn{4}{|c|}{$\begin{array}{l}\text { SIMD ranking. } \\
\text { Ranked by proportion of their SIMD } \\
\text { in the } 0-15 \% \text { band }\end{array}$} \\
\hline & 2004 & 2006 & 2009 & 2012 \\
\hline Aberdeen City & 12 & 12 & 11 & 12 \\
\hline Aberdeenshire & 25 & 23 & 25 & 23 \\
\hline Angus & 23 & 21 & 21 & 25 \\
\hline Argyll and Bute & 16 & 19 & 19 & 19 \\
\hline Clackmannanshire & 15 & 15 & 17 & 16 \\
\hline Dumfries and Galloway & 16 & 18 & 18 & 17 \\
\hline Dundee City & 5 & 5 & 5 & 4 \\
\hline East Ayrshire & 11 & 11 & 12 & 10 \\
\hline East Dunbartonshire & 22 & 25 & 25 & 25 \\
\hline East Lothian & 28 & 28 & 28 & 25 \\
\hline East Renfrewshire & 21 & 25 & 23 & 20 \\
\hline City of Edinburgh & 4 & 3 & 3 & 5 \\
\hline Eilean Siar & 28 & 29 & 30 & 29 \\
\hline Falkirk & 13 & 13 & 15 & 13 \\
\hline Fife & 8 & 6 & 6 & 3 \\
\hline Glasgow City & 1 & 1 & 1 & 1 \\
\hline Highland & 16 & 14 & 16 & 14 \\
\hline Inverclyde & 7 & 7 & 9 & 9 \\
\hline Midlothian & 27 & 24 & 25 & 25 \\
\hline Moray & 28 & 29 & 29 & 29 \\
\hline North Ayrshire & 9 & 9 & 7 & 8 \\
\hline North Lanarkshire & 2 & 2 & 2 & 2 \\
\hline Orkney Islands & 28 & 29 & 30 & 29 \\
\hline Perth and Kinross & 23 & 20 & 21 & 22 \\
\hline Renfrewshire & 6 & 8 & 7 & 7 \\
\hline Scottish Borders & 25 & 25 & 23 & 23 \\
\hline Shetland Islands & 28 & 29 & 30 & 29 \\
\hline South Ayrshire & 14 & 17 & 14 & 14 \\
\hline South Lanarkshire & 3 & 4 & 4 & 6 \\
\hline Stirling & 20 & 22 & 20 & 20 \\
\hline West Dunbartonshire & 10 & 9 & 10 & 11 \\
\hline West Lothian & 16 & 16 & 13 & 17 \\
\hline
\end{tabular}

Source: Based on Scottish Government, $2012^{89}$.

These fuel poverty and SIMD income domain metrics, although not directly comparable in terms of raw numbers and reporting periods can be effectively compared through 
ranking at local authority level. Consistently these rankings show that urban areas are more deprived according to the SIMD income domain, whereas rural areas rank highest for fuel poverty according to the SHCS method. This is illustrated by Figure 3, which is constructed from data from these two sources.

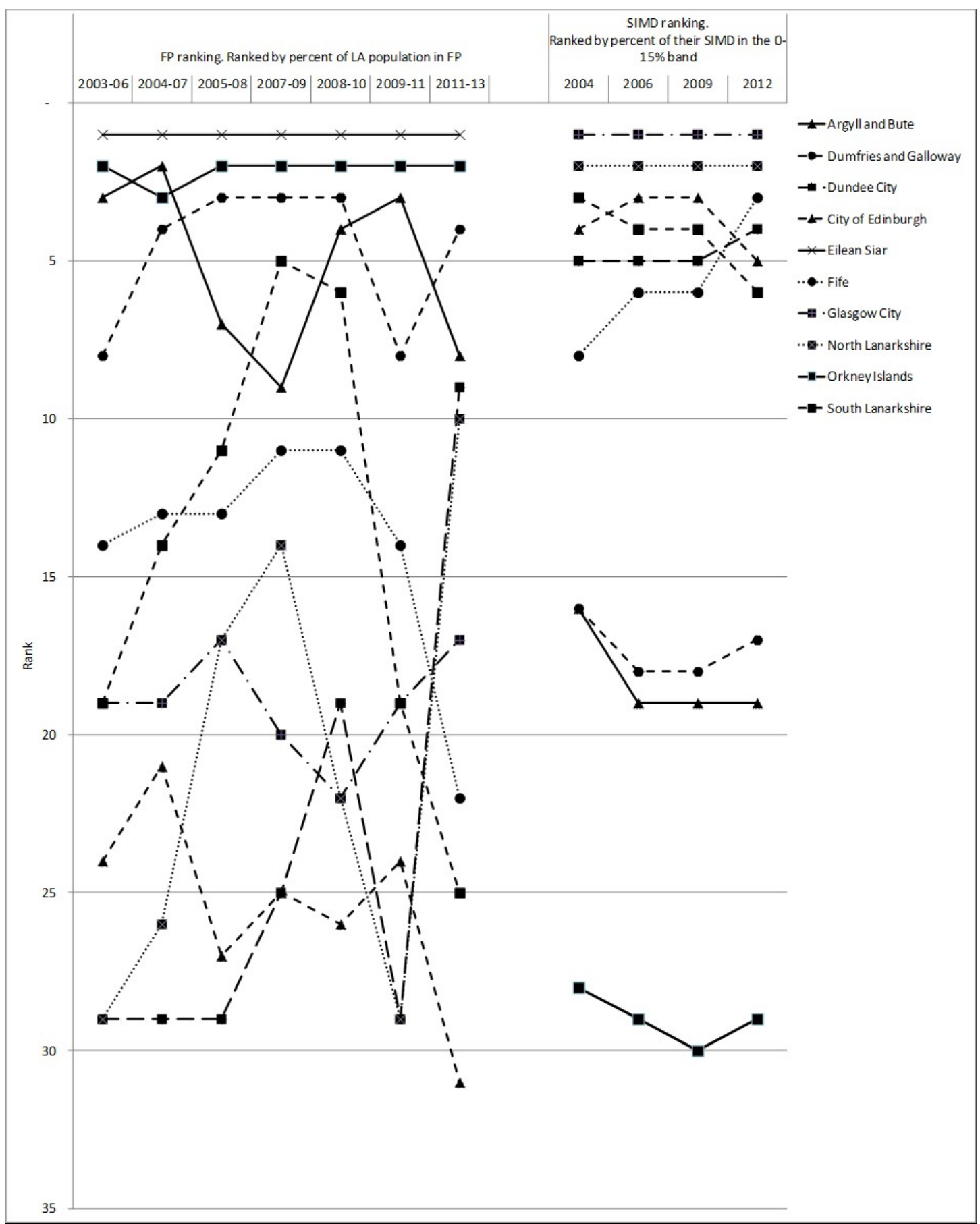

Figure 3. Scottish local authorities ranked according to the percentages of households in fuel poverty and percentages of households in the 0-15\% SIMD income band Note: For the SIMD rankings Eilean Siar tracks the Orkney Islands. 
Finally, in order to ascertain the significance, or otherwise, of the relationship between the distributions of fuel poverty reported by the two methods, the data were analysed using a simple paired t-test ${ }^{92}$. Since the data was collected in different time scales they are not consistently comparable, and so the fuel poverty figures were tested against the SIMD figures for the middle of each three year period, therefore the SIMD rankings for 2004, 2006 and 2009 were compared against the fuel poverty rankings for 2003-06, 2005-08 and 2008-10 respectively. The results, shown in Table 5, return a t-critical value of 2.040 and two tail p values of $0.684,0.672$ and 0.946 , and so the null hypothesis that the two samples are equal can be rejected and it is possible to conclude that the income domain of SIMD does not have a statistically significant relationship with the distribution of fuel poverty as reported by the SHCS method.

Table 5. Paired t-test analysis of SIMD and fuel poverty statistics

\begin{tabular}{llll}
\hline & $\begin{array}{l}\mathbf{2 0 0 4} \text { vs 2003- } \\
\mathbf{0 6}\end{array}$ & $\begin{array}{l}\mathbf{2 0 0 6} \mathbf{~ v s} \\
\mathbf{2 0 0 5 - 0 8}\end{array}$ & $\begin{array}{l}\mathbf{2 0 0 9} \mathbf{~ v s} \\
\mathbf{2 0 0 8}-\mathbf{1 0}\end{array}$ \\
\hline $\begin{array}{l}\text { Hypothesized Mean } \\
\text { Difference }\end{array}$ & 0.000 & 0.000 & 0.000 \\
\hline $\mathbf{d f}$ & 31.000 & 31.000 & 31.000 \\
\hline $\mathbf{t}$ Stat & 0.068 & 0.428 & 0.410 \\
\hline $\mathbf{P}(\mathrm{T}<=\mathrm{t})$ two-tail & 0.946 & 0.672 & 0.685 \\
\hline $\mathbf{t}$ Critical two-tail & 2.040 & 2.040 & 2.040 \\
\hline
\end{tabular}

Therefore, in light of the weaknesses of these approaches in capturing, illustrating and understanding local and national geographies of fuel poverty, particularly in rural and island areas, the opportunity to conduct a meso-scale analysis of actual energy consumption data in a local authority with a boundary spanning a deprived urban area (the town of Paisley and the edge of the Glasgow conurbation) and deprived rural areas (Kilbarchan, Lochwinnoch) was seen as particularly valuable for informing Scottish policy.

\section{Methodology}

In common with the six previous UK studies the Renfrewshire study was conducted by accessing actual (as opposed to modelled) household energy data, and using a range of standard statistical techniques to investigate the significance of a range of technical and socio-demographic factors in explaining the underlying variances in the data. The general approach has numerous benefits, including mitigating the risk of the Hawthorne effect, 
whereby knowledge of participating in a study may influence behaviour ${ }^{93}$, and being agnostic to 'known knowns' by avoiding the use of assumptions and proxies.

The Renfrewshire study was conducted by obtaining gas data for 1,536 households in local authority housing managed by Renfrewshire Council. These were gas bills issued by the supplier during 2013-15. Estimated and partial readings were removed from the dataset and the address details were matched to the local authority housing stock database and the Home Energy Efficiency Database (HEED) ${ }^{94}$, a national database on technical parameters, and cross-checked as far as possible with local databases maintained by the council to support its in-house fuel poverty advocacy services. Although the local authority housing stock database and the related datasets from the advocacy services were used as the primary sources, as they are updated following any home visits for property maintenance and household support, the HEED data was used as an additional supplementary source for cross-checking building characteristics where any doubt existed. The stock is all owned by the local authority and subject to a regular maintenance regime, meaning there are no notable differences in the stock quality and energy efficiency between the urban and rural that might otherwise limit the interpretation of the results, as all are required to meet the Scottish Housing Quality Standard ${ }^{95}$. The number of variables was further reduced by restricting the analyses to households with mains gas central heating as their primary form of heating, all of which were also fitted with A-rated condensing combi boilers and standard meters from a single energy supplier.

Household energy consumption and expenditure data was collected from energy bills for over 1,500 of these households, 452 which met the conditions and were deemed robust enough to be valid for analysis, as they were based on actual meter readings by trained meter readers from the energy supplier (as opposed to readings supplied by the householders). The data collection period was between July 2011 and March 2013, which includes two heating seasons.

Access to the raw data was restricted to council computers and all data was held and managed in accordance with the UK's Data Protection Act ${ }^{12}$. These conditions, along with provisions made under the 1996 revision of the UK's Welfare Reform Act ${ }^{11}$, allowed for the data to be accessed and analysed without requiring householders' permission, and in doing so exploited substantial amounts of data that is already being collected but is not normally accessible to academic researchers.

The data was collated in spreadsheet (Excel and SPSS) format and interrogated using a range of standard statistical techniques and tests including descriptive analysis ${ }^{96}$, multiple regression, t-tests ${ }^{83}$, two-step cluster analysis and box plots. In order to gain a better understanding of the data and their relationships, painstaking exploratory data analysis was undertaken rather than the use of automated statistical procedures such as stepwise regression. Although commonly used, these approaches confer little understanding of the underlying data, and are in any case open to criticism on technical grounds ${ }^{97}$. Further arguments against their use in similar studies include the high risk of assigning high levels of significance to chance features of the data that bear no relation to established knowledge; the tendency to produce $r^{2}$ values that are biased towards being high; the 
production of inaccurate p-values (ANOVA significance values) that are very difficult to correct for; and difficulties in accounting for evidence of collinearity within smaller populations $^{98,99,100,101,102,103,104}$.

The records were categorized as urban, peri-urban and rural based on a simplified (aggregated) version of the Scottish Government's urban rural classification categories ${ }^{105}$. As noted in the Introduction, the use of Renfrewshire as the study area exploited an opportunity to gather data from council-owned housing stock from one of the few Scottish local authorities whose boundaries include substantial urban and rural areas. This enabled statistically useful numbers of households to be classified into aggregated urban and rural categories, with a smaller number of households classified as peri-urban - these being those in larger rural settlements contiguous on at least one side with the Greater Glasgow / Paisley urban conurbation. This conurbation is the largest urban area in Scotland and all other the seven cities exhibit lower degrees of urban sprawl, and so these settlements are particularly characteristic of the Renfrewshire administrative area (Figure 4).

Whilst the influence of the distinct urban-rural divide on housing densities still means that the sample population is biased (in this case towards urban households) this discrepancy has been controlled for as far as possible, and the alternative of working across two or more councils would have added significant complications and costs for data gathering. It also enabled the study to target householders on lower incomes, whilst also being representative of the local authority's housing stock by capturing householders on middle and higher incomes. The main reason for this targeting was simply that lower income households are more exposed to the risks of falling into fuel poverty, and that the influence of rurality appears to exacerbate these risks. However, it was also informed by a further hypothesis that there is a high enough level of variation in energy expenditure amongst the lowest income households to question the validity of assuming a linear relationship between income and energy expenditure (see Figure 2). 


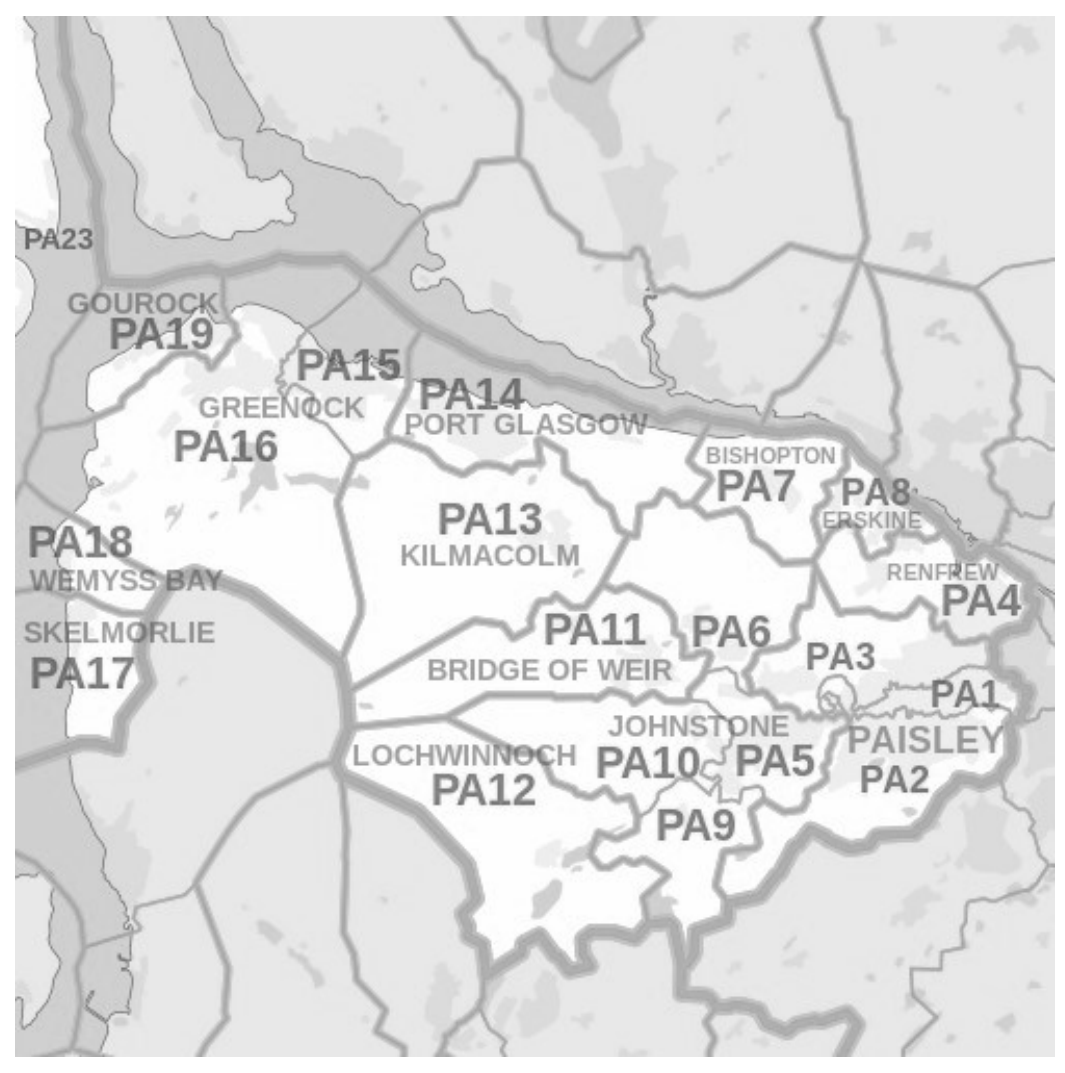

Figure 4. The Renfrewshire Council administrative area ${ }^{106}$

Note: Within the local authority boundary the light grey areas (around Paisley,

Kilmacolm, etc, denote urban areas) and the darker grey areas denote the coast and inland waters.

Source: Wikipedia, created from the Office of National Statistics Postcode Directory data, 2012. Republished under the conditions of the Creative Commons AttributionShareAlike License.

The partnership with Renfrewshire Council also enabled the data collected to be verified, as far as possible, against additional sources accessible to the council but not generally (or at least freely) accessible to academic researchers, such as records collected as part of managing and maintaining the properties. This means that the resulting dataset is at least as accurate and robust as any held by local or central government whilst not drawing on sources not commonly accessible to them, and so enabling the work to be conducted and replicated without the need for bespoke surveying.

\section{Analysis and Discussion}

Once the 452 records deemed sufficiently robust were filtered from the full dataset the first concern was to ensure it was contiguous in time and not weighted towards the summer or winter periods, as the seasonal variation in heating use would skew the results. Figure 5 shows this is not significant, with the distributions generally conforming to the 
expected seasonal spend pattern, and with no significant data gaps. A further concern with the dataset was that the means of collection meant that the data was not contiguous in time and so could be skewed by differences in the two heating seasons however, Figure 5 shows this is not significant, with the distributions generally conforming to the expected seasonal spend pattern.

This emphasis on ensuring the records were as robust and accurate as possible means that it was not possible to be certain that all household types were systematically represented throughout the data collection period. However, as for the previous six studies, the numbers of records needed to produce meaningful results increases with every variable to be analysed, and so is a known limitation of the approach. A further limitation is the level of variation introduced by the proportion of gas used for cooking however, this is negligible compared to that used for heating and evidence from the previous studies suggests it is strongly influenced by other household characteristics, and therefore difficult to analyse directly at this scale. As such, the intention was not to capture a universal representation of every variable, but to focus on analyzing the household gas expenditure data against those variables for which there were the greatest levels of control (SIMD income decile, rurality), whilst using analyses against the other variables (dwelling types, numbers of householders, etc) to compare the levels of consistency with findings from the previous six studies. The data were initially subjected to a battery of statistical tests to test for evidence, or otherwise, of the strength, or otherwise, of the influences identified by the previous UK studies that could suggest evidence of one or more factors skewing the results. However, although some of these influences were found to be less significant than found elsewhere, no notable anomalous or unusually strong relationships were found.

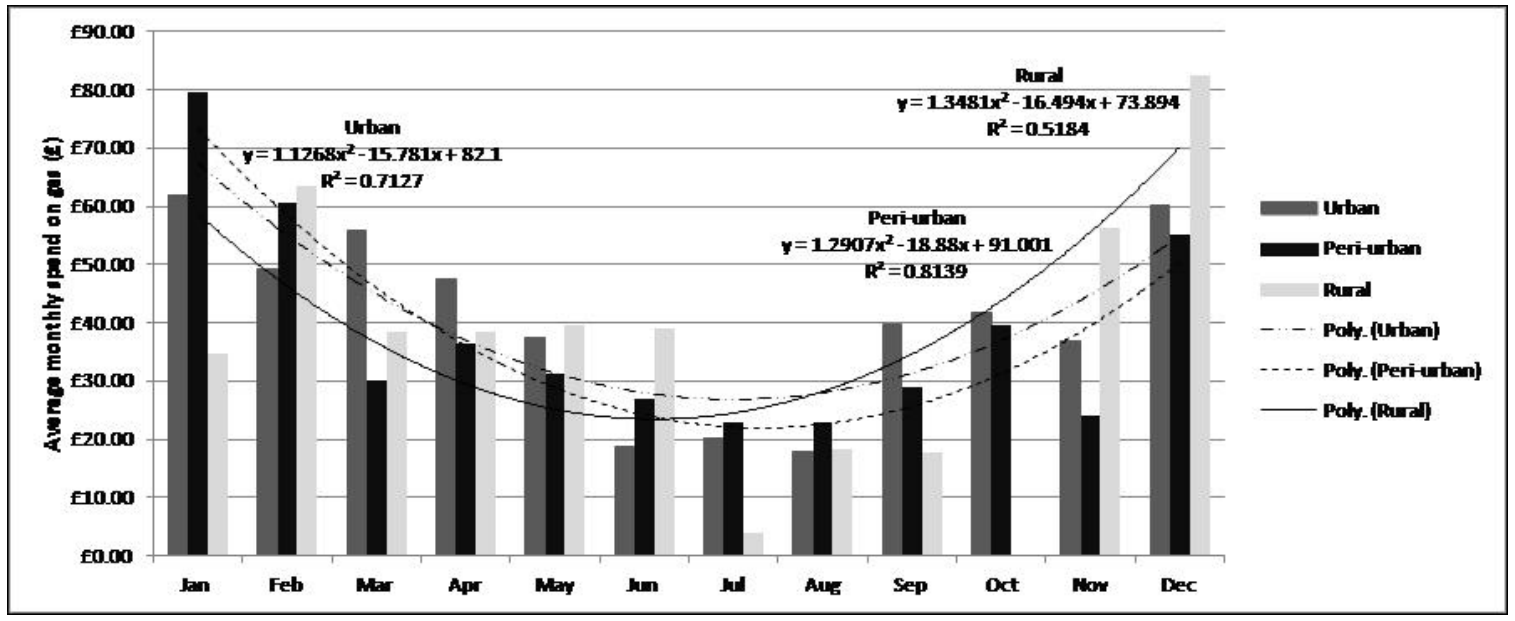

Figure 5. Average monthly gas spend ( $£$ ) by urban / rural classification

However, as show in Figure 5, the household data collected was heavily weighted to the lower end of the daily amount spent on fuel (Figure 6) and the samples are similarly weighted to the lower income deciles (Figure 7) (the modal average being decile 2). This factor shows the aim of explicitly targeting low income areas was achieved, and is a key 
differentiator between this and the previous studies. The statistics show a strong correlation between income and expenditure on gas, and the overall mean average is $£ 1.80$ /day which is slightly lower than the national average of $£ 1.88$ /day. Table 6 shows the descriptive statistics for household daily spend on fuel for heating and hot water by income decile, as illustrated in Figure 8.

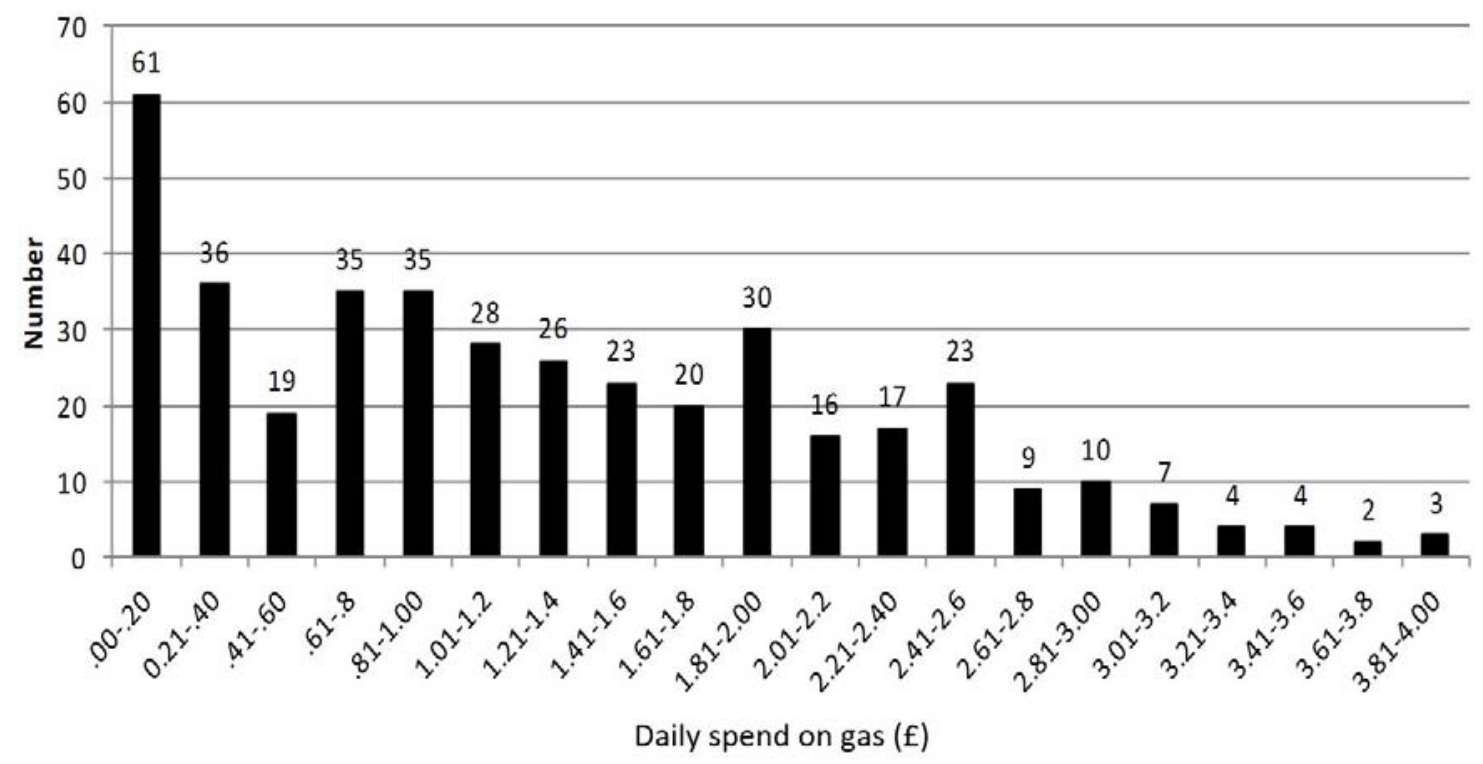

Figure 6. Number of households by daily spend on gas (£)

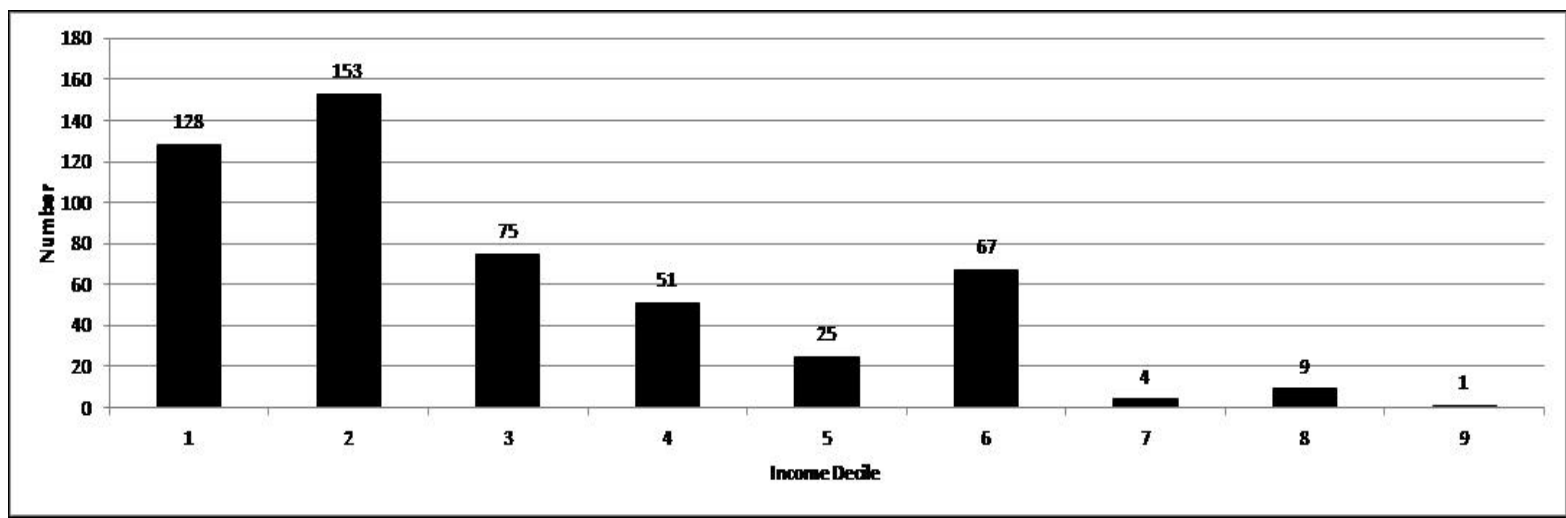

Figure 7. Number of households by SIMD income decile 
Table 6. Daily spend on gas (£) for heating by SIMD income decile

\begin{tabular}{llll}
\hline SIMD decile & Mean (£) & Count & $\begin{array}{l}\text { Standard } \\
\text { deviation }\end{array}$ \\
\hline 1 & 1.79 & 128 & 3.06 \\
\hline 2 & 1.76 & 153 & 2.02 \\
\hline 3 & 2.08 & 75 & 2.97 \\
\hline 4 & 2.18 & 51 & 2.25 \\
\hline 5 & 1.94 & 25 & 1.39 \\
\hline 6 & 2.45 & 67 & 2.92 \\
\hline 7 & 1.61 & 4 & 0.69 \\
\hline 8 & 2.18 & 9 & 1.95 \\
\hline 10 & 6.7 & 1 & 4.9 \\
\hline
\end{tabular}

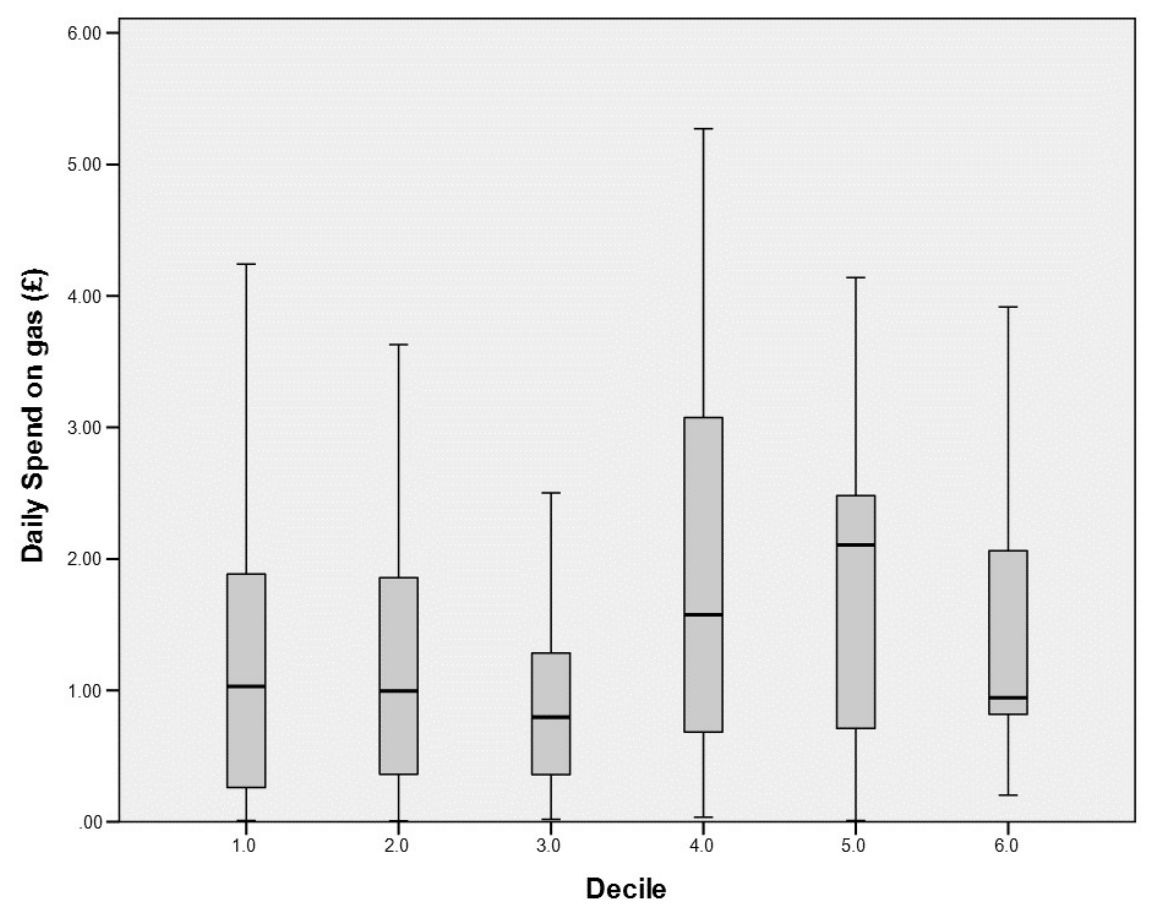

Figure 8. Daily spend on gas (£) by SIMD income decile 
The results show a very high degree of variance in daily fuel spend across the income deciles - even in the lowest income decile there were households spending more on fuel per day than the average spend of those in the eighth decile. Although there still appears to be an increasing trend in the population averages with increasing income deciles, and so a regression analysis was used to test the strength of the relationship between income decile and daily spend on gas (Figure 9).

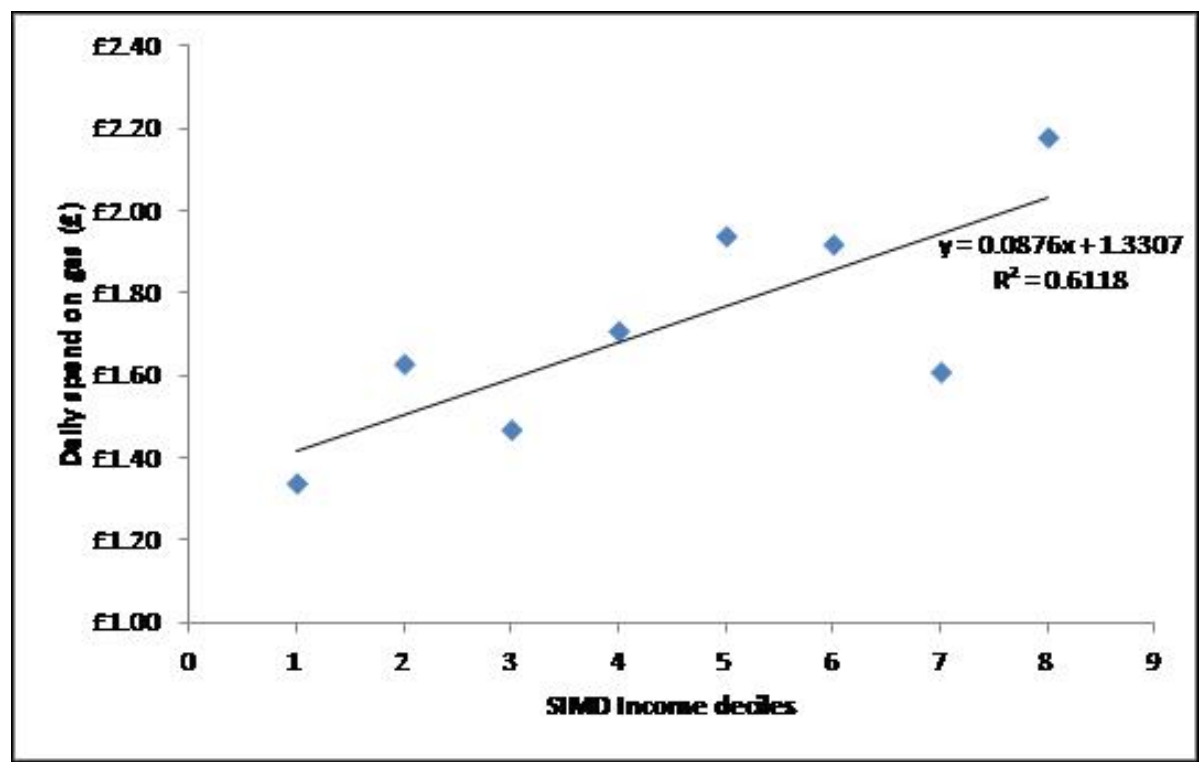

Figure 9. Average daily spend on gas (£) against SIMD income decile

At this stage, assuming equal variances, the SIMD income decile explains the majority of the variation in fuel spend on heating $\left(\mathrm{r}^{2}=0.6118, \mathrm{~F}\right.$ value 0.375 , $\mathrm{p}$ value 0.094$)$, and this increases to $\mathrm{r}^{2}=0.7585$ when outliers greater than 1.5 times the interquartile range are removed. However, due to the likely presence of fuel poor households exhibiting nonstandard behaviours such as self-limiting energy use, these outliers should not be assumed to be due to inaccuracies in the data. These values may appear high, but are not quite as high as reported in official statistics for the UK, which also assume equal variances ${ }^{115}$. A further comment here is that, for the purposes of understanding and addressing fuel poverty, we are more concerned with how much of the variation in heating demand is explained by the SIMD income statistic for households in the lowest deciles (1 to 3), where we would expect to see greater variation due to such non-standard behaviours.

It should be noted that, because this data is for expenditure on gas only, we did not set out to use it to test whether DECC's assumption that the distribution of household energy spend is not significantly and strongly skewed, which was evident in its statistical reporting ${ }^{107}$ and which we have questioned in a letter to New Scientist ${ }^{108}$. However, if this was the case, as suggested by the initial findings from our latest research ${ }^{109}$, then this would have clear implications for policy making. This will be the subject of future publications, but at this stage there appears to be evidence to at least question this assumption. 
It should also be noted that, although the numbers of households in deciles 7 to 9 is very small, this makes no difference to the analysis that follows. The data has been included for the sake of transparency, and to show that, as would be expected, local authority housing includes a small number of higher income households whose energy spend is not inconsistent with the generally assumed trend. Furthermore, as suggested by DECC's statistics (the variation at the upper end of the trend shown in Figure 2), and by recent research $^{2}$, it would appear that the strength of the income / fuel spend relationship may be breaking down amongst households in the highest income deciles, and therefore had the Renfrewshire fuel spend data for these deciles shown even greater variation it would still not necessarily suggest any problems with the dataset.

Following this, the dataset was used to test the hypothesis that there is no significant difference between the fuel spend of urban and rural households. Figure 10 and Table 8 show the breakdown of the data by the postcodes, which are classified as urban, periurban or rural using a simplified form of the Scottish Government classification ${ }^{105}$. This was made possible due to the distinct urban-rural divide in the council area - the urban areas cover the town of Paisley and the fringe of the Glasgow conurbation, and the periurban classification denotes Johnstone, a small town sharing an urban border with the Paisley and Greater Glasgow conurbation but otherwise surrounded by rural areas (see Figure 4).

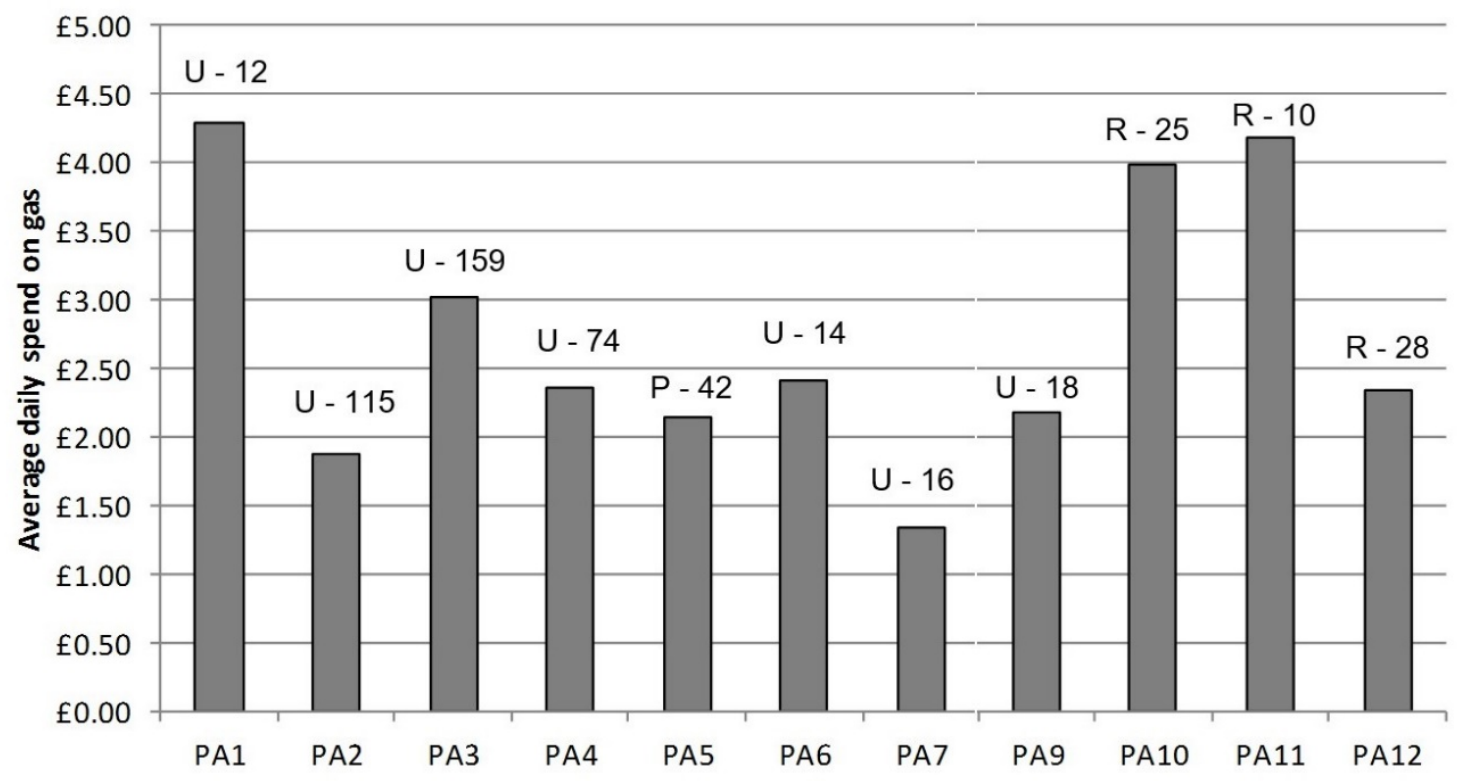

Figure 10. Mean daily spend on gas ( $£$ ) by postcode, rurality and household count

Note: $\mathrm{U}=$ Urban, $\mathrm{P}=$ Peri-urban, $\mathrm{R}=$ Rural. Numbers denote household counts in each postcode area.

This difference becomes more apparent when daily spend on gas is plotted against the SIMD income domain deciles. The distributions of the expenditure of low income rural and peri-urban households are distinctly different to those of urban households, which 
follow a general trend of increasing expenditure with increasing income however, this distinction only becomes clear when the data in the deciles is binned into low, medium and high income households (Figure 11).

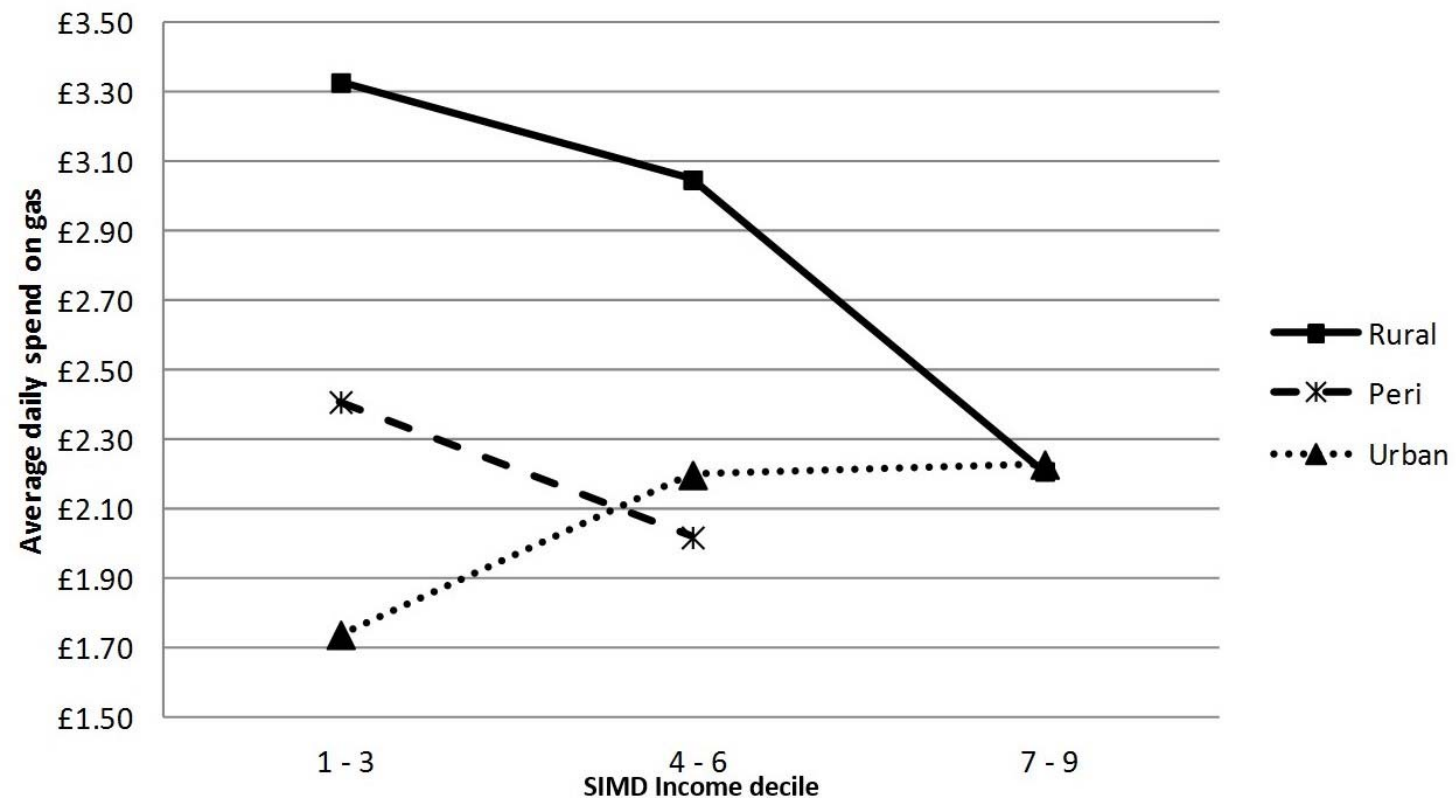

Figure 11. Mean daily spend on gas ( $£$ ) by binned SIMD income domain decile and urban / rural classification

What Figure 11 shows is clear evidence of a phenomenon that has to date only been reported anecdotally, that the amount rural households spend on heating actually decreases with increasing income, and yet grouping data in this way (the use of 0 to $15 \%$, $20 \%$ and $25 \%$ income bands) is common in Scottish statistics and policymaking. This is further confirmed by t-test analyses (Tables 7, 8, and 9).

It should be noted that the smaller numbers of households in the rural, and especially the peri-urban, samples present some limitations to the strength of these findings however, as shown in Figure 4 the seasonal distributions of expenditure on gas are sufficiently consistent across all three groups to be able to conclude that these differences have not introduced any significant error or deviation from what would be expected. Furthermore, whilst the numbers of households in deciles 7 to 9 are so small that the data is included for transparency only and nothing should be inferred from the differences with households in lower income deciles. The emphasis of this study was on determining differences between those on lower incomes and the rest of the population (i.e. between deciles 1 to 3 and 4 and above), and so this limitation does not affect our conclusions. The intention here is simply to present the data as completely and transparently as possible. 
Table 7. Urban versus rural t-test results

\begin{tabular}{lll}
\hline T test analysis $-\mathbf{H}_{\mathbf{0}}: \boldsymbol{\mu}_{\text {urban= }} \boldsymbol{\mu}_{\mathrm{rural}}$ & $\begin{array}{l}\text { Assuming } \\
\text { equal } \\
\text { differences }\end{array}$ & $\begin{array}{l}\text { Assuming unequal } \\
\text { differences }\end{array}$ \\
\hline $\mathrm{df}$ & 445.0000 & 50.0000 \\
\hline $\mathrm{t}$ Stat & -2.7493 & -2.1984 \\
\hline $\mathrm{P}(\mathrm{T}<=\mathrm{t})$ two-tail & 0.0062 & 0.0326 \\
\hline $\mathrm{t}$ Critical two-tail & 1.9653 & 2.0086 \\
\hline
\end{tabular}

Table 8. Urban versus peri-urban t-test results

\begin{tabular}{lcc}
\hline $\begin{array}{l}\text { T test analysis. } \\
\mathbf{H}_{0}: \boldsymbol{\mu}_{\text {Peri-urban }}=\boldsymbol{\mu}_{\text {Rural }}\end{array}$ & Assuming equal differences \\
\hline $\mathrm{df}$ & -0.980 & 401.0000 \\
\hline $\mathrm{t}$ Stat & -0.8179 \\
\hline $\mathrm{P}(\mathrm{T}<=\mathrm{t})$ two-tail & 0.330 & 0.4139 \\
\hline $\begin{array}{l}\text { t Critical two- } \\
\text { tail }\end{array}$ & 1.991 & 1.9659 \\
\hline
\end{tabular}

Table 9. Urban versus peri-urban and rural t-test results

\begin{tabular}{ll}
\hline T test analysis. & Assuming equal differences \\
$\mathbf{H}_{\mathbf{0}}: \boldsymbol{\mu}_{\text {Urban }}=\boldsymbol{\mu}_{\text {Rural }+ \text { Peri-urban }}$ & \\
\hline $\mathrm{df}$ & 445.0000 \\
\hline $\mathrm{t} \mathrm{Stat}$ & -2.4470 \\
\hline $\mathrm{P}(\mathrm{T}<=\mathrm{t})$ two-tail & 0.0148 \\
\hline $\mathrm{t}$ Critical two-tail & 1.9653
\end{tabular}

These analyses disprove the hypothesis that the amount spent on fuel in rural and urban areas is equal. $\mathrm{P}$ values assuming equal difference $\left(\mathrm{P}_{\text {equal }}\right.$ is 0.0062$)$ and assuming unequal differences ( $\mathrm{P}_{\text {unequal }}$ is 0.0326 ) are both indicative of a statistically significant difference.

The housing in the peri-urban area is dominated by semi-detached properties or four in a block flats. These properties are more widely dispersed with larger garden areas than the urban properties. The comparison of peri-urban against rural $(\mathrm{P}=0.33)$ and urban postcodes $(\mathrm{P}=0.4139)$ does not show a significant difference between peri-urban and the other populations, but there may be a bias towards the former. 
These findings are also supported by those from recent survey carried out as part of a national campaign ${ }^{110}$, and could suggest rural households are exhibiting a difference in the prebound effect ${ }^{57}$, which would also be contingent with other findings that show the additional complexity inherent in understanding and addressing fuel poverty amongst rural and otherwise more vulnerable households ${ }^{111,112,113,114}$. Further reasoning for this is that the prebound effect appears to be rooted in cultural differences, and in Scotland there is a widely-held perception that there are distinctions between the cultures of urban and rural communities that is both contingent with the results of these studies, and which could reasonably be expected to manifest themselves in attitudes and behaviours related to energy consumption. For example, rural communities are generally perceived as being more close-knit and resilient, the consequences of which might reasonably include having more permeable thresholds due to occupants and visitors coming and going more, and possibly also maintaining higher indoor temperatures during the day. Further research is being planned to test these tentative hypotheses.

To conclude, we argue that it is this highly complex mix of influences, rather than predetermined geographic boundaries, socio-economic groupings, and consumer archetypes that ultimately influences the real geographies of fuel poverty in Scotland. This, therefore, poses questions as to how effective policies intended to address fuel poverty can ever be whilst they remain rooted in conventional social science and 'fabric first' led approaches. As Castellani (2014) ${ }^{85}$ argues, this level of complexity calls for a radically different approach to policy making, and whilst defining such an approach will be the subject of further research, at this stage we suggest there are clear grounds for treating fuel poverty as a condition distinct from energy inefficiency, and which may be better aligned with risk-based policy making mechanisms for addressing health, welfare and vulnerability-related problems.

\section{Conclusions}

The key aim of this study was to use the data held by Renfrewshire Council on actual (as opposed to modelled) household gas expenditure and other technical, social and economic data held on its housing stock database and records collected by its fuel poverty advocacy services, cross-checked against supplementary sources, to investigate common assumptions about the distribution of fuel poverty in Scotland. Foremost amongst these was the influence of the distinct urban-rural divide, and the validity of using the income domain of the Scottish Indices of Multiple Deprivation (SIMDs) as a proxy measure for identifying fuel poor households, particularly in rural areas. The findings are necessarily limited by the aim of informing Scottish policy, but they demonstrate the application of an approach that, if validated and expanded and scaled to a national level, could be used as part of the development of a risk-based approach to addressing fuel poverty. The first element of this work, the expansion and validation of these findings across Scotland, has been funded by the Eaga Charitable Trust ${ }^{109}$ and will be the subject of further academic publications.

In an international context these results demonstrate that, because of the inherent complexity of fuel poverty and the difficulties (and costs) of measuring it directly, any 
given metric will have weaknesses that must be understood and accounted for in the design of policies and programmes in order to avoid inaccurately representing local geographies of fuel (or energy) poverty. Furthermore, as the generally accepted definition of energy poverty includes all necessary household energy use, it seems only logical to expect that these difficulties are greater, and the risks of misrepresenting local geographies correspondingly higher. However, this and other socio-economic studies have shown that it is possible to mitigate those risks by supporting policy making with analyses of real (as opposed to modelled) household energy data and other robust data commonly held by local authorities.

Within Scotland the influence of rurality on fuel poverty levels is now acknowledged in official statistics but, as the results show, it is still not accurately quantified nor sufficiently understood. The use of the SIMD income domain and fuel poverty rankings (Figure 3) has influenced policy towards employing mechanisms to enhance rural fuel poverty mitigation, but the continued and consistent prevalence of high levels of fuel poverty in rural and island areas shows that there remains a bias in the metrics, or at least in the ways they are used, which continues to favour households in urban areas. As such this analysis shows that the current policy responses are not sufficient to achieve the impacts that they aspire to achieve, and based on these findings and conclusions from the wider research presented here we argue that this is because those responses are based on approaches that insufficiently sensitive to those local geographies and the complex factors and influences that underlie the condition of fuel poverty, particularly in rural Scotland.

These findings, if found to apply across the country as a whole would have significant implications for fuel poverty policy, not least because they suggest that it is being insufficiently captured and under-reported in rural areas. They raise questions over the fitness-for-purpose of both the datazones and the SIMD income domain in identifying fuel poor households in Scotland for accurately capturing these real but hidden geographies and targeting households in or at risk of fuel poverty. As a result, we argue that there is a clear case for reconsidering how the SIMD income domain is used in future policies and programmes, and this study provides some evidence to inform any future changes to the boundaries and use of the datazones for estimating numbers of fuel poor households, particularly in rural areas.

Whilst it is not our intention to question the validity of the Scottish definition of fuel poverty, indeed quite the opposite given the widespread criticism of the alternative now adopted for England, its key strength of being rooted in robust evidence from building science also limits its sensitivity to the range of factors and influences that underlie the resulting condition of households being unable to afford adequate levels of warmth. Therefore there is a potentially significant benefit to be derived from a qualitative riskbased metric which further enables the identification of, and leads to better engagement with, those most vulnerable to fuel poverty and its impacts. This is not to dismiss the existing definition as this is still effective at normalising many of the influencing factors, and makes the meaningful reporting on the condition affordable. However, the data and 
its analysis presented here demonstrate that there are hidden geographies of fuel poverty which cannot be sufficiently captured by it.

The findings add to the growing body of evidence supporting the assertion that distinctly different policy approaches are needed for tackling fuel poverty in rural and island Scotland, which should not be based on the standard assumptions used for driving fuel poverty policies for urban areas, and which should be sensitive to the more complex influences on the energy behaviours of these households. It may even be advisable that policy making for fuel poverty should be decoupled across the urban-rural divide, with the latter being built around the delivery of more localised approaches that are more reflective of these more complex hidden geographies.

Finally, we conclude that these hidden geographies exist through variations in household behaviour which are not addressed effectively through current programmes - for example, current programmes will deliver new central heating without considering whether the resident has the understanding, the ability or the desire to use that system as recommended. Therefore, we argue, developing and implementing a more sensitive qualitative risk assessment-based approach to the targeting and selection of measures to support to fuel poor households may have a more positive effect on the health and wellbeing of the Scottish population than is currently achievable by metric-driven programmes.

\section{Acknowledgements}

The authors wish to acknowledge the support of Glasgow Caledonian University and Renfrewshire Council, without whom this study would not have been possible. The review for Citizen's Advice Scotland ${ }^{10}$ was conducted in parallel with the final stages of this study and does not contribute any empirical findings to this paper, but did enable more time to be spent on reading relevant literature.

\section{Funding Statement}

This research was made possible by a $\mathrm{PhD}$ studentship funded internally by Glasgow Caledonian University and in-kind support from Renfrewshire Council. Towards the end of the study period the authors received funding from the Eaga Charitable Trust for a study to expand on and validate the approach and findings across other areas of Scotland ${ }^{109}$, the results of which will be published in future papers.

\section{Data Protection Statement}

The data analysed for this study was collected, stored, managed and used in full compliance with the UK Data Protection ${ }^{12}$ and Welfare Reform ${ }^{11}$ Acts. Access to the raw (non-anonymised) data was, and is, restricted to computers within the council's secure network. 


\section{Conflict of Interest Statement}

The authors declare no conflicts of interest associated with this study.

\section{Author Declaration}

Both authors contributed equally in the preparation of this manuscript. 


\section{References}

${ }^{1}$ Jones RV, Fuertes A, and Lomas KJ. The socio-economic, dwelling and appliance related factors affecting electricity consumption in domestic buildings.

Renew Sustain Energy Rev 2015; 43: 901-917.

${ }^{2}$ Jones RV and Lomas KJ. Determinants of high electrical energy demand in UK homes: Socio-economic and dwelling characteristics. Energy and Buildings 2015; 101: 24-34.

${ }^{3}$ Perkins A. The Influence of Urban Form on Life Cycle Transport and Housing Energy and Greenhouse Gas Emissions. Report, School of Geoinformatics, Planning and Building, University of South Australia.

${ }^{4}$ Baker KJ and Rylatt M. Improving the prediction of UK domestic energy demand using annual consumption data. Appl Energy 2008; 85: 475-482.

${ }^{5}$ Druckman A and Jackson T. Household energy consumption in the UK: A highly geographically and socio-economically disaggregated model. Energy Policy 2008; 36: 3177-3192.

${ }^{6}$ Hamilton IG, Steadman PJ, Bruhns HR, Summerfield, A, and Lowe, R. Energy efficiency in the British housing stock: energy demand and the Homes Energy Efficiency Database. Energy Policy 2013; 60: 462-480.

${ }^{7}$ Summerfield AJ, Lowe RJ, Bruhns HR, Caeiro JA, Steadman JP and Oreszczyn T. Milton Keynes Energy Park revisited: changes in temperatures and energy usage. Energy Build 2007; 37: 783-791.

${ }^{8}$ Wyatt P. A dwelling-level investigation into the physical and socio-economic drivers of domestic energy consumption in England. Energy Policy 2013; 60: 540-549.

${ }^{9}$ Scottish Government. Scottish House Condition Survey 2014, www.gov.scot/Topics/Statistics/SHCS (2015, accessed 11 October 2016).

${ }^{10}$ Maiden T, Baker KJ, and Faulk A, 2016. Taking the Temperature: A Review of Energy Efficiency and Fuel Poverty Schemes in Scotland. Report for Citizens Advice Scotland, Edinburgh, UK, June 2016.

${ }^{11}$ National Archives. Welfare Reform Act 2012, www.legislation.gov.uk/ukpga/2012/5/contents/enacted/data.htm (2012, accessed 11 October 2016).

${ }^{12}$ National Archives. Data Protection Act 1998, www.legislation.gov.uk/ukpga/1998/29/contents (1998, accessed 11 October 2016). 
${ }^{13}$ European Parliament. Legislative resolution of 18 June 2008 on the proposal for a directive of the European Parliament and of the Council amending Directive 2003/54/EC concerning common rules for the internal market in electricity. $J$ Eur Union 2008; C 286 E/106.

${ }^{14}$ González-Equino M. 2015. Energy poverty: An overview. Renewable and Sustain Energy Rev 2015; 47: 377-385.

${ }^{15}$ European Commission. Commission Staff Working Paper: An Energy Policy for Consumers. Report, European Commission, Brussels, Belgium, 2010.

16 Pantazis C, Gordon D and Levitas R. Poverty and social exclusion in Britain. The millennium survey: Studies in Poverty, Inequality and Social exclusion, 2nd Edition. The Policy Press, University of Bristol, UK, 2010.

${ }^{17}$ Wang K, Wang Y-X, Li K, and Wei, Y-M., 2015. Energy poverty in China: An index based comprehensive evaluation. Energy Policy 2015; 47: 308-323.

${ }^{18}$ Buzar S. The 'hidden’ geographies of energy poverty in post-socialism: Between institutions and households. Geoforum 2007; 38: 224-240.

19 Legendre B and Ricci, O. 2013. Measuring fuel poverty in France: which households are the most vulnerable? Energy Econ 2015; 49: 620-628.

20 Thomson H, and Snell C. Quantifying the prevalence of fuel poverty across the European Union. Energy Policy 2013; 52: 563-572.

${ }^{21}$ Nolay P. EPEE Project: European Fuel Poverty and Energy Efficiency. Report, Intelligent Energy Europe, France, 2014.

${ }^{22}$ Bouzarovski, S. Petrova S. and Sarlamanov R. Energy poverty policies in the EU: a critical perspective. Energy Policy 2012; 49: 76-82.

${ }^{23}$ Pye P, Dobbins A, and Baffert C. Energy poverty and vulnerable consumers in the energy sector across the EU: analysis of policies and measures. Report, European Commission, May 2015.

${ }^{24}$ Lloyd B. Fuel Poverty in New Zealand. Social Policy $J$ N Z, 2006; 27: 142-155.

${ }^{25}$ Scottish Executive. Housing (Scotland) Act 2001, www.legislation.gov.uk/asp/2001/10/contents (2001, accessed 11 October 2016).

${ }^{26}$ Scottish Executive. Scottish Fuel Poverty Statement, www.gov.scot/Resource/Doc/46951/0031675.pdf (2002, accessed 11 October 2016). 
${ }^{27}$ National Archives. The Electricity Act 1989, www.legislation.gov.uk/ukpga/1989/29/pdfs/ukpga_19890029_en.pdf (1989, accessed 11 October 2016).

${ }^{28}$ Office of Gas and Electricity Markets. The Energy Company Obligation, www.ofgem.gov.uk/environmental-programmes/eco (2016, accessed 11 October 2016).

${ }^{29}$ Scottish Government. National Planning Framework, www.gov.scot/Topics/BuiltEnvironment/planning/National-Planning-Framework (2016, accessed 11 October 2016).

${ }^{30}$ Energy Saving Trust. Home Energy Efficiency Programmes, www.energysavingtrust.org.uk/scotland/grants-loans/heeps (2016, accessed 11 October 2016).

${ }^{31}$ Scottish Government. Scotland's Energy Efficiency Programme, www.gov.scot/Topics/Business-Industry/Energy/Action/lowcarbon/LCITP/SEEP (2016, accessed 11 October 2016).

${ }^{32}$ Boardman, B. Seasonal mortality and cold homes. In: Unhealthy Housing: A Diagnosis conference, Warwick, UK, 14-16 December 1986, University of Warwick.

${ }^{33}$ Boardman B. Fuel Poverty: From Cold Homes to Affordable Warmth. London: Belhaven Press.

${ }^{34}$ Boardman B. Fuel poverty synthesis: Lessons learnt, actions needed. Energy Policy 2012; 49: 143-148.

${ }^{35}$ Moore R. Definitions of Fuel Poverty: Implications for policy. Energy Policy 2012; 49: 19-26.

${ }^{36}$ Price CW. Brazier K. and Wang W. Objective and subjective measures of fuel poverty. Energy Policy 2012; 49: 33-39.

${ }^{37}$ Hills J. Getting the measure of Fuel Poverty. Report for the Department of Energy and Climate Change, Case Report 72, March 2012, London.

38 Department for Energy and Climate Change. Trends in fuel poverty England: 2003 to 2010, www.gov.uk/government/statistical-data-sets/trends-in-fuel-poverty-england2003-to-2010 (2013, accessed 11 October 2016).

${ }^{39}$ World Health Organisation. Indoor Environment: Health Aspects of Air Quality, Thermal Environment, Light and Noise. Report, World Health Organisation 1990, Geneva, Switzerland. 
40 Jenkins, D. The value of retrofitting carbon-saving measures into fuel poor social housing. Energy Policy 2010; 38: 832-839.

${ }^{41}$ White, V. Beyond average consumption: Development of a framework for assessing impact of policy proposals on different consumer groups. Report for the Office of Gas and Electricity Markets, 2014, London, UK.

42 European Union. Energy Performance of Buildings (EPBD) Directive. European Union Directive 2002/91/EC, and as amended in 2010/31/EU.

${ }^{43}$ Affinity Sutton. FutureFit: Final Report Part 2. Report, Affinity Sutton, UK, July 2013.

${ }^{44}$ Baker KJ, Emmanuel R and Phillipson M. Support for RPP2 - Housing

Futures. Report for ClimateXChange Scotland, Edinburgh and Glasgow, UK, 2012.

${ }^{45}$ Baker, KJ, Emmanuel, R and Phillipson M. Support for RPP2 - Abatement Built Environment. Report for ClimateXChange Scotland, Edinburgh and Glasgow, UK, 2012.

${ }^{46}$ Beckmann K, \& Roaf S. Climate Resilience for the Scottish Built Environment. Report for ClimateXChange Scotland, Edinburgh and Glasgow, UK, 2013.

${ }^{47}$ Consumer Focus Scotland. Consumer Focus Scotland's response to the Scottish Government Building Standards Division Consultations on: Section 63: Energy Performance of Non-Domestic Buildings; and Energy Performance of Building Directive - Recast. Report, Consumer Focus Scotland, Edinburgh, UK, 2012.

48 Jones Lang LaSalle. A Tale of Two Buildings: Are EPCs a true indicator of energy efficiency? Report, Better Buildings Partnership, UK, 2012.

${ }^{49}$ Sanders C and Phillipson M. Review of Differences between Measured and Theoretical Energy Savings for Insulation Measures. Report for the Energy Saving Trust, Glasgow, UK, 2006.

${ }^{50}$ UK Green Building Council. Zero-Carbon Non-Domestic Buildings. Report, UK Green Building Council, March 2010.

${ }^{51}$ Cambridge Architectural Research. Modelling Greenhouse Gas Emissions from Scottish Housing: Final Report. Report for the Scottish Government, Edinburgh, UK, 2009.

${ }^{52}$ Greening LA, Greene DL and Difiglio C. Energy efficiency and consumption — the rebound effect — a survey. Energy Policy 2000; 28: 389-401.

${ }^{53}$ Sorrell S. Jevons' paradox revisited: the evidence for backfire from improved energy efficiency. Energy Policy 2009; 37: 1456-1569. 
${ }^{55}$ Galvin R. Estimating broad-brush rebound effects for household energy consumption in the EU 28 countries and Norway: some policy implications of Odysee data. Energy Policy 2014; 73: 323-332.

${ }^{55}$ Madlener M and Hauertmann, M. Rebound Effects in German Residential Heating: Do Ownership and Income Matter? Report, FCN Working Paper no. 2/2011, Energy Research Centre, RWTH-Aachen University, February 2011.

${ }^{56}$ Galvin R. The rebound effect, gender and social justice: A case study in Germany. Energy Policy 2015; 86: 759-769.

${ }^{57}$ Galvin R, and Sunikka-Blank M. Introducing the prebound effect: the gap between performance and actual energy consumption. Build Res Infor 2012; 40: 260-273.

${ }^{58}$ Annesi-Maesano I, Lundbäck B and Viegi G. Respiratory epidemiology. 1st ed. Sheffield: European Respiratory Society, 2014.

${ }^{59}$ Bernstein J, Alexis N, Bacchus H, Bernstein LI, Fritz P, Horner E, Li N, Mason S, Nel A, Oulette J, Reijula K, Reponen T, Seltzer J, Smith A, and Tarlo SM. The health effects of nonindustrial indoor air pollution. J Allergy Clin Immunol 2008; 121: 585-591.

${ }^{60}$ Bornehag C, Blomquist G, Gyntelberg F, Järvholm B, Malmberg P, Nordvall L, Nielsen A, Pershagen G and Sundell J. Dampness in Buildings and Health. Nordic Interdisciplinary Review of the Scientific Evidence on Associations between Exposure to "Dampness" in Buildings and Health Effects (NORDDAMP). Indoor Air 2001; 11: 7286.

${ }^{61}$ Scottish Government. A Select Review of Literature on the Relationship Between Housing and Health. Report, Communities Analytical Services Division, Scottish Government, Edinburgh, UK, 2010.

${ }^{62}$ Douglas M, Thomson H, and Gaughan M. Health Impact Assessment of Housing Improvements: A Guide. Report, Public Health Institute of Scotland, Glasgow, UK, 2003.

${ }^{63}$ Fisk W, Lei-Gomez Q, and Mendell, M. Meta-analyses of the associations of respiratory health effects with dampness and mold in homes. Indoor Air 2007; 17: 284296.

${ }^{64}$ Grant C, Hunter C, Flannigan B, and Bravery AF. The moisture requirements of moulds isolated from domestic dwellings. Int Biodeterior 1989; 24: 259-289.

${ }^{65}$ Howden-Chapman P, Viggers H, Chapman R, O'Sullivan K, Telfar Barnard L and Lloyd B. Tackling cold housing and fuel poverty in New Zealand: A review of policies, research and health impacts. Energy Policy 2012; 49: 134-142. 
${ }^{66}$ Jones AP. Indoor air quality and health. Atmos Environ 1999; 33: 4535-4564.

${ }^{67}$ Kim K, Jahan S, and Kabir E. A review on human health perspective of air pollution with respect to allergies and asthma. Environ Int 2013; 59: 41-52.

${ }^{68}$ Liddell C and Morris C. 2010. Fuel poverty and human health: A review of recent evidence. Energy Policy 2010; 38: 2987-2997.

${ }^{69}$ Mendell M, Mirer A, Cheung, K, Tong M and Douwes J. Respiratory and Allergic Health Effects of Dampness, Mold, and Dampness-Related Agents: A Review of the Epidemiologic Evidence. Environmental Health Perspectives 2011; 119: 748-756.

${ }^{70}$ Nandasena S, Wickremasinghe A and Sathiakumar N. Respiratory health status of children from two different air pollution exposure settings of Sri Lanka: A cross-sectional study. Am J Ind Med 2012; 55: 1137-1145.

${ }^{71}$ Nicolaou, N, Siddique N and Custovic, A. Allergic disease in urban and rural populations: increasing prevalence with increasing urbanization. Allergy, 2005; 60: 13571360.

${ }^{72}$ Norbäck D, Björnsson E, Janson C, Widstrom J, and Boman G. Current asthma and biochemical signs of inflammation in relation to building dampness in dwellings. Int $J$ Tuberculosis Lung Dis 1999; 3: 368-376.

${ }^{73}$ Park J-H, Schleiff PL, Attfield MD, Cox-Ganser JM and Kreiss K. Building-related respiratory symptoms can be predicted with semi-quantitative indices of exposure to dampness and mold. Indoor Air 2004; 14: 425-433.

${ }^{74}$ Perez-Padilla R, Schilmann A, and Riojas-Rodriguez H. Respiratory health effects of indoor air pollution. Int J Tuberculosis Lung Dis 2010; 14: 1079-1086.

75 Taske N, Taylor L, Mulvihill C and Doyle N. Housing and public health: a review of reviews of interventions for improving health. Evidence Briefing the National Institute for Health and Care Excellence (NICE), UK, 2005.

${ }^{76}$ Teedon PL, Gillespie M, and Lindsay K, and Baker K. Parental perceptions of the impacts the built environment has on young children's health: a qualitative examination and lay assessment amongst residents in four Scottish communities. Health Place 2014; 28: 50-57.

${ }^{77}$ Welch L. Severity of health effects associated with building-related illness. Environ Health Perspect 1991; 95: 67-69.

${ }^{78}$ Wolkoff P, Clausen PA, Jensen B, Nielsen GD, and Wilkins CK. Are We Measuring the Relevant Indoor Pollutants? Indoor Air 1997; 7: 92-106. 
${ }^{79}$ Zuraimi M, Tham K, Chew F, and Ooi P. The effect of ventilation strategies of child care centers on indoor air quality and respiratory health of children in Singapore. Indoor Air 2007; 17: 317-327.

${ }^{80}$ Anderson W, White V and Finney A. Coping with low incomes and cold homes. Energy Policy 2012; 49: 40-52.

${ }^{81}$ Consumer Focus Scotland. Changed Lives: The real cost of high fuel bills: The impact of rising energy prices on struggling households in Scotland. Report, Consumer Focus Scotland, Edinburgh, UK, 2013.

${ }^{82}$ Middlemiss L and Gillard R. Fuel poverty from the bottom-up: Characterising household energy vulnerability through the lived experience of the fuel poor. Energy Res Social Sci 2015; 6: 146-154.

83 Ürge-Vorsatz D and Tirado Herrero. Building synergies between climate change mitigation and energy poverty alleviation. Energy Policy, 2012; 49: 83-90.

${ }^{84}$ Scottish Government, High level summary of statistics trend: Fuel poverty, www.gov.scot/Topics/Statistics/Browse/Housing-Regeneration/TrendFuelPoverty (2016, accessed 22 February 2017).

${ }^{85}$ Castellani B. Complexity and the failure of quantitative social science. Discover Society, November 2014.

${ }^{86}$ Liddell C, Morris C, McKenzie SJP, and Rae G. Measuring and monitoring fuel poverty in the UK: national and regional perspectives. Energy Policy 2012; 38: 27-32.

${ }^{87}$ Scottish Government. Scottish Neighbourhood Statistics, Scottish Index of Multiple Deprivation, Interactive Mapping, www.gov.scot/Topics/Statistics/SIMD/SIMDInteractive (2013, accessed 11 October 2016).

${ }^{88}$ Morris J, Allinson D, Harrison J, and Lomas KJ. Benchmarking and tracking domestic gas and electricity consumption at the local authority level. Energy Effic 2016; 9: pp 723743.

${ }^{89}$ Scottish Government. Scottish Index of Multiple Deprivation 2012: National Statistics data for the Scottish Government, http://simd.scotland.gov.uk/publication-2012/ (2012, accessed 11 October 2016).

${ }^{90}$ Department for Energy and Climate Change. National Energy Efficiency DataFramework (NEED) table creator, www.gov.uk/government/statistical-data-sets/needtable-creator (2015, accessed 11 October 2016). 
${ }^{91}$ National Records of Scotland. Mid-2014 Small Area Population Estimates Scotland: Detailed Data Zone Tables, www.nrscotland.gov.uk/statistics-anddata/statistics/statistics-by-theme/population/population-estimates/2011-based-specialarea-population-estimates/small-area-population-estimates/mid-2011-to-mid-2014 (2015, accessed 11 October 2016).

92 McDonald JH. Handbook of Biological Statistics. 3rd ed. Baltimore, Maryland: Sparky House Publishing, 2014.

${ }^{93}$ Grubb MJ. Energy efficiency and economic fallacies. Energy Policy 1990; 18: 783785.

${ }^{94}$ Energy Saving Trust. Home Energy Efficiency Database (HEED), https://homeanalytics.est.org.uk/heedonline/ (2014, accessed 11 October 2016).

${ }^{95}$ Scottish Government. Scottish Housing Quality Standard, www.gov.scot/Topics/BuiltEnvironment/Housing/16342/shqs (2015, accessed 23 February 2017)

${ }^{96}$ Helsel DR and Hirsch RM. Statistical methods in water resources. Studies in Environmental Science 49. New York: Elsevier Science Ltd, 1993.

97 Judd CM and McClelland GH. Data analysis: a model comparison approach. New York: Harcourt Brace Jovanovich, 1989.

98 Altman DG and Andersen PK. Bootstrap investigation of the stability of a cox regression model. Stat Med 1989; 8: 771-783.

${ }^{99}$ Copas JB. Regression, Prediction and Shrinkage. $J$ R Stat Soc, Ser B (Methodol) 1983; 45: 311-354.

${ }^{100}$ Derksen S and Keselman, HJ. Backward, forward and stepwise automated subset selection algorithms: Frequency of obtaining authentic and noise variables. $\mathrm{Br} \mathrm{J}$ Math Stat Psychol 1992; 45: 265-282.

${ }^{101}$ Hurvich CM and Tsai CL. The Impact of Model Selection on Inference in Linear Regression. Am Stat 1990; 44: 214-217.

102 Mantel N and Valand RS. A Technique of Nonparametric Multivariate Analysis. Biometrics 1970; 26: 547-558.

${ }^{103}$ Roecker EB. Prediction Error and Its Estimation for Subset-Selected Models. Technometrics 1991; 33: 459-468.

104 Tibshirani R. Regression Shrinkage and Selection via the Lasso. J R Stat Soc, Ser B (Methodol) 1996; 58: 267-288. 
${ }^{105}$ Scottish Government. Scottish Government Urban / Rural Classification, www.gov.scot/Topics/Statistics/About/Methodology/UrbanRuralClassification (2014, accessed 11 October 2016).

${ }^{106}$ Wikipedia. Renfrewshire, en.wikipedia.org/wiki/Renfrewshire (2014, accessed 11 October 2016).

${ }^{107}$ Department for Energy and Climate Change. Energy Consumption in the UK, www.gov.uk/government/publications/energyconsumption-in-the-uk, (2013, accessed 11 October 2016).

${ }^{108}$ Baker KJ and Mould R. Chronic energy woes. New Scientist, $12^{\text {th }}$ July 2014, p. 26.

${ }^{109}$ Baker KJ, Mould R, and Restrick S. Proiseact Speird - The Speird Project: Understanding influences on fuel poverty in rural and island Scotland. Report for the Eaga Charitable Trust, UK, October 2016.

${ }^{110}$ Spowart N. Rural areas 'hit hardest by rise in fuel poverty'. The National, 30 May 2015.

${ }^{111}$ George M, Graham C, and Lennard L. The Energy Penalty: Disabled People and Fuel Poverty. Report for the Eaga Charitable Trust, University of Leicester, UK, 2013.

112 Snell C. Fuel poverty and disabled people: the impact of policy change. Report for the Eaga Charitable Trust, York University, UK, 2013.

${ }^{113}$ MacInnes T, Aldridge H, Bushe S, Tinson A and Born TB. Monitoring poverty and social exclusion. Report for the Joseph Rowntree Foundation, UK, 2014.

${ }^{114}$ Kenway P, Bushe, S, Tinson A. Monitoring Poverty and Social Exclusion in Scotland. Report for the Joseph Rowntree Foundation, UK, March 2015. 